Prepared in cooperation with Yakama Nation Fisheries, Pacific Northwest National Laboratory, McNary Fisheries Compensation Committee, and the Bureau of Reclamation

\title{
Movements of Juvenile Pacific Lamprey (Entosphenus tridentatus) in the Yakima and Columbia Rivers, Washington, 2018-A Pilot Study Using Acoustic Telemetry
}

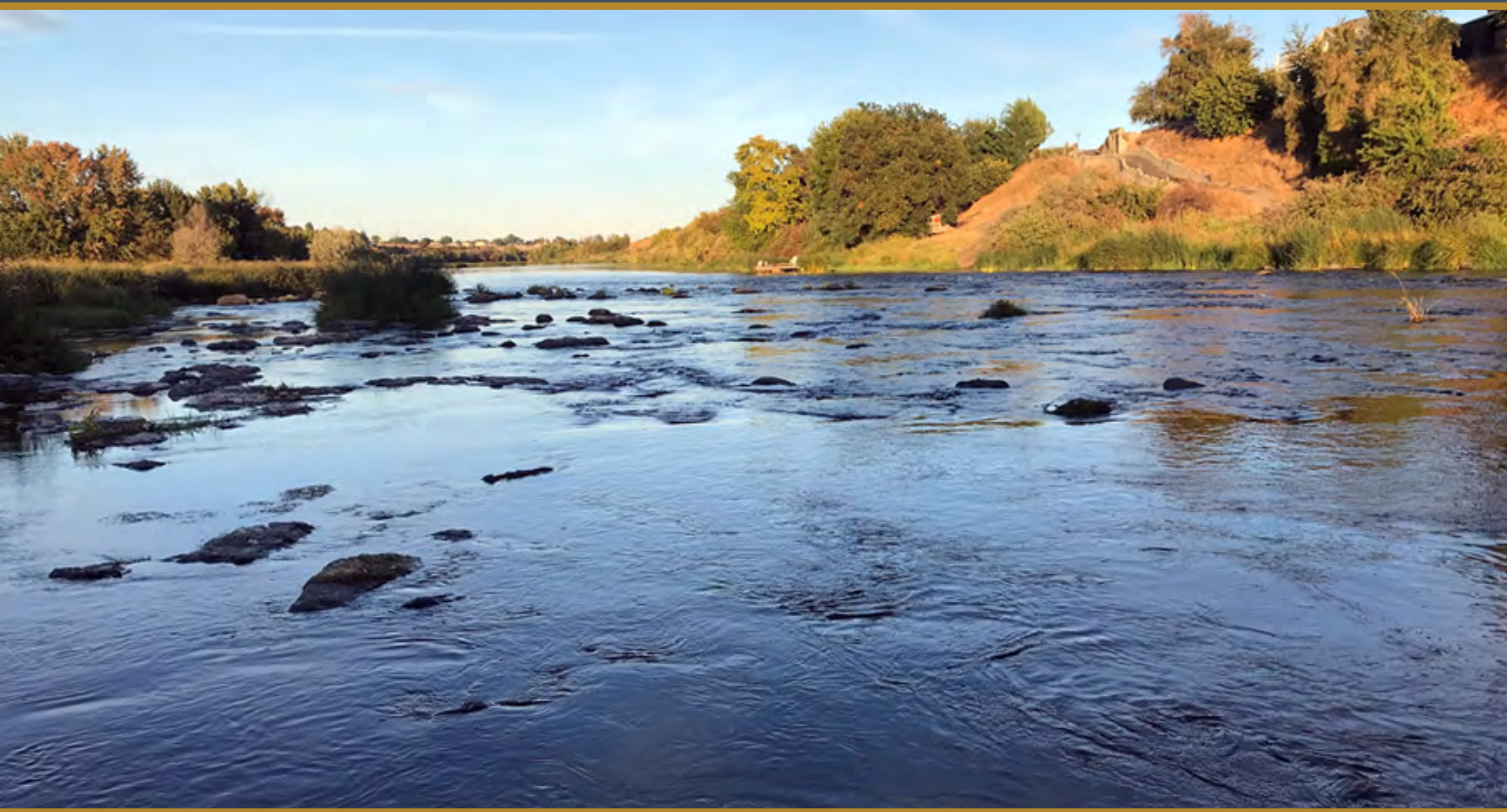

Open-File Report 2019-1058

U.S. Department of the Interior

U.S. Geological Survey 
Cover: Downstream view of Yakima River at river kilometer 73, downstream of Interstate 82 bridge at Prosser, Washington. Photograph by Tyler Beals, Yakama Nation Fisheries, September 20, 2018. 


\section{Movements of Juvenile Pacific Lamprey (Entosphenus tridentatus) in the Yakima and Columbia Rivers, Washington, 2018-A Pilot Study Using Acoustic Telemetry}

By Theresa L. Liedtke, Ralph T. Lampman, Daniel Z. Deng, Tyler E. Beals, Michael S. Porter, Amy C. Hansen, Tobias J. Kock, Ryan G. Tomka, and Patrick Monk

Prepared in cooperation with Yakama Nation Fisheries, Pacific Northwest National Laboratory, McNary Fisheries Compensation Committee, and the Bureau of Reclamation

Open-File Report 2019-1058

U.S. Department of the Interior U.S. Geological Survey 


\section{U.S. Department of the Interior \\ DAVID BERNHARDT, Secretary}

\section{U.S. Geological Survey James F. Reilly II, Director}

U.S. Geological Survey, Reston, Virginia: 2019

For more information on the USGS-the Federal source for science about the Earth, its natural and living resources, natural hazards, and the environment-visit https://www.usgs.gov/ or call 1-888-ASK-USGS (1-888-275-8747).

For an overview of USGS information products, including maps, imagery, and publications, visit https://store.usgs.gov/.

Any use of trade, firm, or product names is for descriptive purposes only and does not imply endorsement by the U.S. Government.

Although this information product, for the most part, is in the public domain, it also may contain copyrighted materials as noted in the text. Permission to reproduce copyrighted items must be secured from the copyright owner.

Suggested citation:

Liedtke, T.L., Lampman, R.T., Deng, D.Z., Beals, T.E., Porter, M.S., Hansen, A.C., Kock, T.J., Tomka, R.G., and Monk, P., 2019, Movements of juvenile Pacific Lamprey (Entosphenus tridentatus) in the Yakima and Columbia Rivers, Washington, 2018-A pilot study using acoustic telemetry: U.S. Geological Survey Open-File Report 2019-1058, 29 p., https://doi.org/10.3133/ofr20191058. 


\section{Contents}

Abstract.

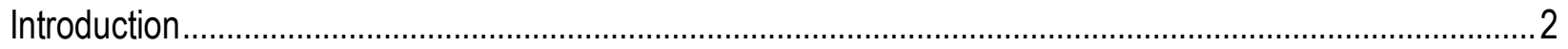

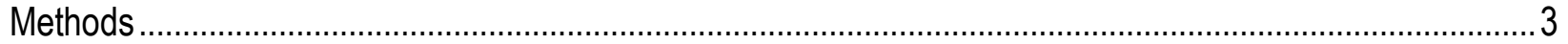

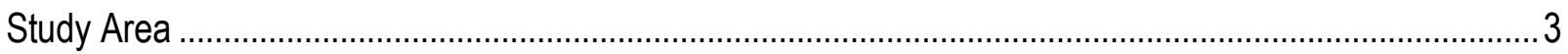

Lamprey Collection, Tagging, and Release ..................................................................................... 4

Monitoring of Tagged Lamprey ...................................................................................................

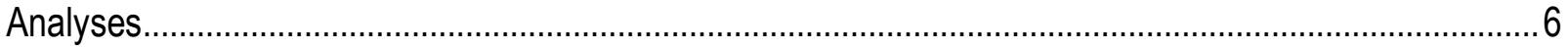

Lamprey Compared to Passive Particle Travel Metrics ………...........................................................

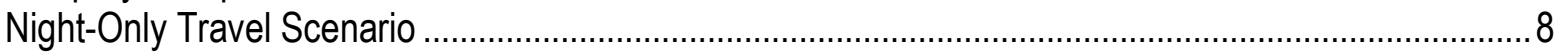

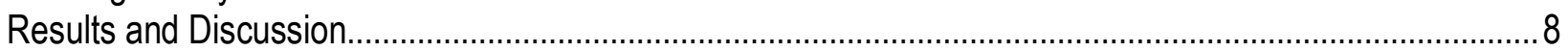

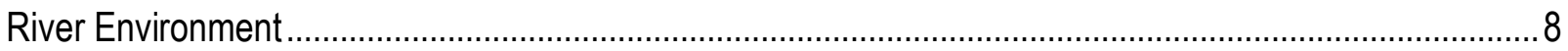

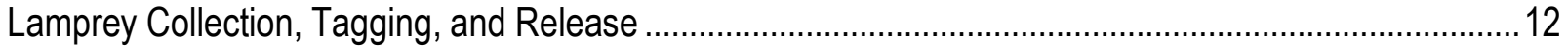

Detection Summary ................................................................................................................... 14

Travel Times, Travel Rates, and Residence Times...........................................................................17

Light Condition at Time of Arrival at Detection Sites ....................................................................... 19

Lamprey Compared to Passive Particle Travel Metrics.......................................................................22

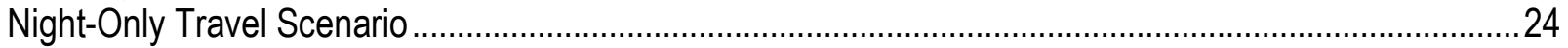

Scenario Rationale and Approach ................................................................................................

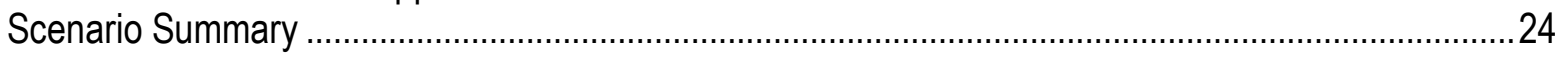

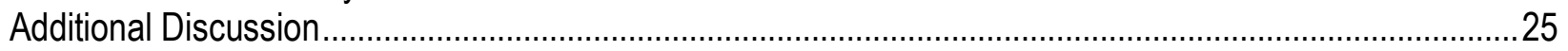

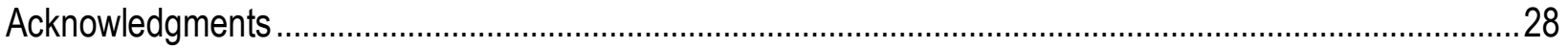

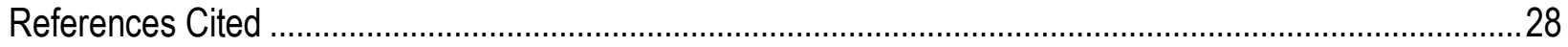

\section{Figures}

Figure 1. Schematic showing eight acoustic telemetry monitoring sites for juvenile Pacific Lamprey in the Yakima River, Washington, 2018 ..........................................................................................

Figure 2. Graph showing discharge and water temperature in Yakima River, Washington, March-

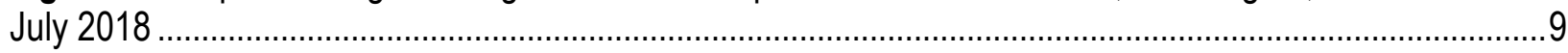

Figure 3. Graph showing releases of acoustically tagged juvenile lamprey and discharge in Yakima River, Washington, May 2018

Figure 4. Graph showing mean daily discharge between McNary Dam tailrace and Bonneville Dam forebay, on the Columbia River, Washington, May 2018 compared to the 10-year (2008-17) mean for May...

Figure 5. Graphs showing number of detections and sites where acoustically tagged juvenile lamprey were detected following release, Yakima and Columbia Rivers, Washington

Figure 6. Graphs showing mean juvenile lamprey travel rates and travel times between McNary and Bonneville Dams for four groups of fish released at two locations in the Yakima River, Washington, May 2018. 


\section{Tables}

Table 1. Acoustic telemetry monitoring sites for juvenile Pacific Lamprey in the Columbia River, Washington, 2018

Table 2. Summary of acoustically tagged juvenile lamprey released at two sites on the Yakima River, Washington, May 2018

Table 3. Mean daily water temperatures for the Columbia River between McNary Dam and Bonneville Dams, on the Columbia River, for May 2018, and for May during the 10-year period, 2008-17.

Table 4. Juvenile lamprey total length and mass for groups of acoustically tagged fish released at two sites on the Yakima River, Washington, May 2018.

Table 5. Release sites and dates, collection sites and dates, and number of days fish were held prior to tagging for groups of acoustically tagged lamprey released at two sites on the Yakima River, Washington, May 2018

Table 6. Monitoring sites where lamprey were detected in the Yakima and Columbia Rivers, by release site and date in 2018, for groups of acoustically tagged lamprey released at two sites on the Yakima River, May 2018.

Table 7. Monitoring sites where no acoustically tagged lamprey were detected in the Yakima River, Washington.

Table 8. Travel time, travel rate, and residence time for groups of acoustically tagged lamprey released under dark and light conditions from two release sites on the Yakima River, Washington, May 2018.

Table 9. Light condition at time of arrival for groups of acoustically tagged juvenile lamprey released under dark and light conditions at two sites on the Yakima River, Washington, May 2018

\section{Conversion Factors}

U.S. customary units to International System of Units

\begin{tabular}{lcc}
\hline \multicolumn{1}{c}{ Multiply } & By & To obtain \\
\hline mile $(\mathrm{mi})$ & Length & kilometer $(\mathrm{km})$ \\
\hline & 1.609 & \\
\hline cubic foot per second $\left(\mathrm{ft}^{3} / \mathrm{s}\right)$ & Flow rate & cubic meter per second $\left(\mathrm{m}^{3} / \mathrm{s}\right)$ \\
\hline & 0.02832 & \\
\hline mile per day $(\mathrm{mi} / \mathrm{d})$ & Travel rate & kilometer per day $(\mathrm{km} / \mathrm{d})$ \\
\hline
\end{tabular}

International System of Units to U.S. customary units

\begin{tabular}{lll}
\hline \multicolumn{1}{c}{ Multiply } & By & To obtain \\
\hline millimeter $(\mathrm{mm})$ & Length & \\
meter $(\mathrm{m})$ & 0.03937 & inch (in.) \\
kilometer $(\mathrm{km})$ & 3.281 & foot (ft) \\
& 0.6214 & mile (mi) \\
\hline & Volume & ounce, fluid (fl. oz) \\
\hline liter $(\mathrm{L})$ & 33.81402 & \\
\hline & Mass & ounce, avoirdupois (oz) \\
milligram $(\mathrm{mg})$ & 0.00003527 & ounce, avoirdupois (oz) \\
\hline
\end{tabular}

Temperature in degrees Celsius $\left({ }^{\circ} \mathrm{C}\right)$ may be converted to degrees Fahrenheit $\left({ }^{\circ} \mathrm{F}\right)$ as follows: ${ }^{\circ} \mathrm{F}=\left(1.8 \times{ }^{\circ} \mathrm{C}\right)+32$ 


\section{Abbreviations}

JSATS Juvenile Salmon Acoustic Telemetry System

PNNL Pacific Northwest National Laboratory

Reclamation Bureau of Reclamation

$S A \quad$ standard deviation

USACE U.S. Army Corps of Engineers

USGS U.S. Geological Survey

YNF Yakama Nation Fisheries 
This page intentionally left blank. 


\title{
Movements of Juvenile Pacific Lamprey (Entosphenus tridentatus) in the Yakima and Columbia Rivers, Washington, 2018-A Pilot Study Using Acoustic Telemetry
}

By Theresa L. Liedtke1, Ralph T. Lampman², Daniel Z. Deng³, Tyler E. Beals², Michael S. Porter², Amy C. Hansen ${ }^{1}$, Tobias J. Kock ${ }^{1}$, Ryan G. Tomka ${ }^{1}$, and Patrick Monk ${ }^{4}$

\begin{abstract}
Telemetry has been an invaluable tool to improve our understanding of adult Pacific Lamprey (Entosphenus tridentatus) movements and to guide management approaches to protect and restore this species of concern. Juvenile and larval lamprey, however, are much smaller than adults, and have not been monitored with telemetry because available transmitters have traditionally been too large. With funding from the U.S. Department of Energy and the U.S. Army Corps of Engineers, the Pacific Northwest National Laboratory developed a prototype micro-transmitter of appropriate size for use in small fish such as juvenile lampreys and eels. Through a collaborative research approach, we used these prototype transmitters to do a pilot level evaluation of juvenile lamprey (macrophthalmia) movements in the Yakima and Columbia Rivers in 2018. Our project monitored tagged lamprey using acoustic monitoring arrays installed and maintained for juvenile salmon (Oncorhynchus spp.) migration studies done by our partners. The study was done in the lower Yakima River, Washington, from river mile 111 to the river mouth, and in the Columbia River, from the Yakima River mouth to Camas, Washington, downstream of Bonneville Dam. We released four groups of tagged lamprey from May 9 to 15 , 2018. Two groups were released at the upper site (located at the State Route 24 bridge, about 4.5 river miles upstream of Wapato Dam), and two groups were released at the lower site (about 1.7 miles upstream of the Yakima River mouth). We detected 95.6 percent of the tagged lamprey, with more individuals detected in the Columbia River than in the Yakima River. Lamprey arrived at Bonneville Dam in an average of 8.0-9.6 days from the upper site (300 river miles) and in an average of 6.5 days from the lower site (193 river miles). Lamprey moved through the study area at an average rate of 30-35 miles per day and generally remained at each detection site for less than about 20 minutes. Most lamprey (63 percent) arrived at detection sites during periods of darkness, but some travel occurred during daylight and transitional light periods.
\end{abstract}

${ }^{1}$ U.S. Geological Survey.

${ }^{2}$ Yakama Nation Fisheries.

${ }^{3}$ Pacific Northwest National Laboratory.

${ }^{4}$ Bureau of Reclamation. 
Overall, lamprey moved more slowly than passive particles in the reach between McNary Dam and Bonneville Dam, but some individuals and one group of lamprey exceed particle travel rates. The estimated particle travel time from McNary Dam to Bonneville Dam was 3.3 days, and the mean travel time for the combined lamprey release groups was 4.4 days. This project is scheduled to complete a similar field study in 2019, continuing the partnership with the Yakima River juvenile salmon study.

\section{Introduction}

Telemetry is a powerful tool for monitoring animal movements. In the Columbia River Basin of the Pacific Northwest, telemetry has been used for decades to evaluate movements, dam passage, and survival of salmon and steelhead (Oncorhynchus spp.; hereinafter "salmon") to inform management decisions to protect and preserve these species. As technology advanced, manufacturers designed and produced smaller and smaller transmitters, responding to the need to monitor the movements of smaller fishes. Small, light transmitters are required for studies of small fishes because telemetry studies assume that tagged individuals behave and perform similarly to untagged individuals. This assumption is not met when the weight of the transmitter relative to the weight of the fish, referred to as transmitter burden, exceeds about 2-5 percent (Liedtke and Wargo-Rub, 2012). In addition to transmitter burden, the size and shape of the transmitter must be considered relative to the fish. Specifically, the transmitter should not disrupt normal swimming or be positioned where it encroaches on internal organs or structures. For example, in laterally compressed fishes, the weight of a transmitter may be appropriate when considering burden, but the transmitter may be too large to fit inside the body cavity. Small transmitters are desirable because they allow a wide range of fishes to be monitored.

Pacific Lamprey (Entosphenus tridentatus), and other lamprey species (Lampetra spp.) pose unique challenges for telemetry studies (Moser and others, 2007), but meeting these challenges is a priority because these unique fishes are not well understood and applying this powerful tool will help to fill knowledge gaps and guide management decisions. Lampreys have long, tube-shaped bodies with cartilaginous skeletons and swim with undulating body movements. All life stages of Pacific Lamprey are associated with substrates and have benthicoriented behavior including burrowing into sediments or attaching to rocks. Combined, these traits can make attachment and retention of a transmitter challenging (Moser and others 2007). Transmitters attached externally could be dislodged by their swimming movements or their regular association with hard substrates. Surgical implantation of the transmitter into the body cavity reduces the risk of transmitter loss (Liedtke and Wargo-Rub, 2012), but the tube-shaped body of lampreys can limit the space available for a transmitter and possibly impede swimming ability (Moser and others, 2002, 2007). Adult Pacific Lamprey commonly are monitored using telemetry (Keefer and others, 2013; Starcevich and others, 2014; McIllraith and others, 2015; Clemens and others, 2017), as implantation techniques have been developed and transmitter burden and dimensions are within defensible limits. We have learned much about adult lamprey movements in and around barriers and in spawning habitats using telemetry (Moser and others, 2002; Johnson and others, 2012; Starcevich and others, 2014; Clemens and others, 2017). Innovative lamprey passage devices have been designed and tested by monitoring how adult lamprey approach and use them (Moser and others, 2011; Keefer and others, 2013). Telemetry has been an invaluable tool to inform adult lamprey movements and to guide management approaches to protect and restore them. Juvenile (macrophthalmia) and larval (ammocoete) lamprey, however, are much smaller than adults, and have not been monitored with telemetry 
because available transmitter models were too large. Juvenile lamprey are of special interest because they are migratory, moving downstream to the ocean, and their migration may be affected by barriers such as dams or water diversions. Managers have been seeking information on juvenile Pacific Lamprey movements for several years, waiting for telemetry technology to advance to the point when a transmitter of appropriate size for this life stage became available.

The Pacific Northwest National Laboratory (PNNL) and the U.S. Army Corps of Engineers (USACE) developed the Juvenile Salmon Acoustic Telemetry System (JSATS) and a micro-transmitter that used micro-battery technology (Deng and others, 2015). The use of microbattery technology enabled advances in transmitter miniaturization, which previously was limited by the size of available batteries. This new transmitter was reported to be "injectable" owing to its small size, which was a benefit because it could reduce the handling typically required to surgically implant a transmitter (Deng and others, 2015). This innovative transmitter weighed 30 percent less than other acoustic transmitters (Deng and others, 2015) and was designed to allow studies of small salmon. Despite the reduction in size, the "injectable" JSATS transmitter was still too large to be used in juvenile lampreys. To address this need, PNNL developed another, smaller transmitter, specifically for use in juvenile lampreys and eels (Deng and others, 2018) with funding from the U.S. Department of Energy and USACE. The transmitter is still undergoing development and testing and is not yet commercially available, but field tests have produced promising results (Deng and others, 2018). Through a collaborative research approach, we used these prototype transmitters to do a pilot level evaluation of juvenile lamprey movements in the Yakima and Columbia Rivers in 2018. We partnered with an ongoing study by U.S. Geological Survey (USGS), the Bureau of Reclamation (Reclamation), and Yakama Nation Fisheries (YNF) that used JSATS to monitor juvenile salmon. The juvenile salmon study had a series of acoustic receivers in the lower $110 \mathrm{mi}$ of the Yakima River that could detect the new lamprey transmitters because they used the JSATS system. Additionally, PNNL had JSATS receivers positioned at several locations in the Columbia River, downstream of the Yakima River. Working collaboratively, we did a pilot-level juvenile Pacific Lamprey evaluation within the study area monitored by these acoustic receivers to begin addressing critical information gaps for this life stage. Some of the information gaps we were especially interested in were (1) movement rates of juvenile lamprey that are relatively weak swimmers (Moursund and others, 2000; Moser and others 2015), and (2) diel movement patterns, as Pacific Lamprey are primarily nocturnal (Moursund and others, 2000).

\section{Methods}

\section{Study Area}

The study was done in the lower Yakima River, from river mile 111 to the river mouth, and in the Columbia River, from the Yakima River mouth to Camas, Washington, downstream of Bonneville Dam. Personnel from the juvenile salmon study installed and maintained acoustic monitoring receivers at eight sites in the Yakima River (fig. 1). Receiver deployments were designed to detect fish as they approached and passed dams or were entrained into irrigation canals. In the Columbia River, the juvenile salmon study and our other study partners maintained acoustic receivers at nine monitoring sites (table 1), including at McNary and Bonneville Dams, 
the Blue Bridge (Pioneer Memorial Bridge) that crosses the Columbia River as U.S. Route 395, and the Cable Bridge (Ed Hendler Bridge) that crosses the Columbia River as State Route 397. Both of these two bridges are near Kennewick, Pasco, and Richland (hereinafter, the "TriCities"), Washington.

\section{Lamprey Collection, Tagging, and Release}

Juvenile Pacific Lamprey were collected at five locations and transported to the Chandler Juvenile Monitoring Facility (hereinafter "the Chandler facility") in Prosser, Washington, for tagging. To supplement fish collected at the Chandler facility, we monitored juvenile lamprey collection efforts at rotary screw traps in Toppenish Creek and Ahtanum Creek (tributaries to the Yakima River) and at the McNary Dam and John Day Dam fish facilities. When juvenile lamprey were collected at these sites within a few days of our tagging date, we transported them to the Chandler facility. All study fish ideally would have been collected from a single location; however, the low collection numbers and unpredictable nature of juvenile lamprey catches required a more flexible approach. We prioritized fish collected at the Chandler facility and the two creeks and only tagged lamprey from the Columbia River dams when fish from these sources were limited.

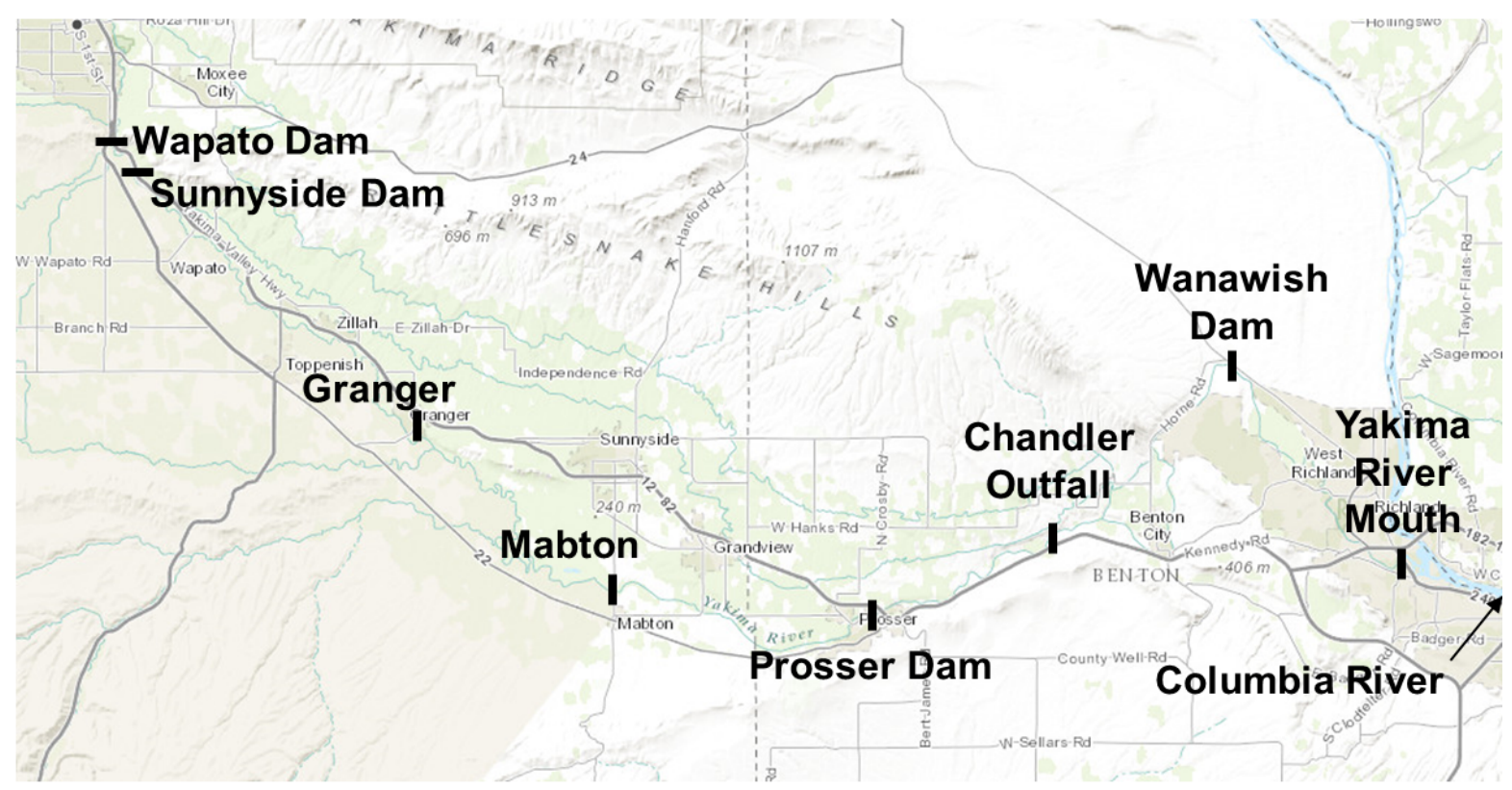

Figure 1. Schematic showing eight acoustic telemetry monitoring sites for juvenile Pacific Lamprey in the Yakima River, Washington, 2018. Monitoring sites on the Columbia River are shown in table 1. 
Table 1. Acoustic telemetry monitoring sites (shown in Columbia River miles) for juvenile Pacific Lamprey in the Columbia River, Washington, 2018.

\begin{tabular}{lc}
\hline \multicolumn{1}{c}{ Monitoring site } & Columbia River mile \\
\hline Blue Bridge & 329.5 \\
Cable Bridge & 327.9 \\
McNary Dam forebay & 292.7 \\
McNary Dam tailrace & 290.8 \\
Crow Butte & 262.2 \\
Klickitat River mouth & 179.9 \\
Bonneville Dam forebay & 146.0 \\
Bonneville Dam tailrace & 143.5 \\
Camas & 119.3 \\
\hline
\end{tabular}

Acoustic transmitters were surgically implanted in the body cavity of juvenile lamprey using techniques described in Mesa and others (2012). Fish handling and aseptic techniques followed principles in Liedtke and others (2012). The prototype transmitter was $12 \times 2 \mathrm{~mm}$, weighed $80 \mathrm{mg}$, and had a 30-day battery life with a pulse rate interval of 5 seconds. The transmitter was developed to match the dimensions of a 12-mm Passive Integrated Transponder, which had been successfully implanted in juvenile lamprey (Mesa and others, 2012). A single experienced tagger was used for all study fish to minimize variability. Fish holding times prior to tagging were variable to allow fish collected over a short period (3-4 days) to be combined in a larger group. Fish were anesthetized individually in a solution of tricaine methanesulfonate (MS$222,100-150 \mathrm{mg} / \mathrm{L}$ ) buffered with an equal amount of sodium bicarbonate. When fish started to become unresponsive, they were removed from the anesthetic, weighed to the nearest $0.1 \mathrm{~g}$, and measured to the nearest $1 \mathrm{~mm}$. Each fish was then placed in a groove cut into a moist closed-cell foam pad saturated with river water. We made a 2-3-mm-long incision 20-22 $\mathrm{mm}$ posterior to the last gill pores with a 3.0-mm microsurgical scalpel (15-degree blade; AngioTech, Vancouver, British Columbia, Canada), inserted the transmitter through the incision, and guided the transmitter anteriorly. No sutures were used to close the incision. The entire tagging procedure (including weighing and measuring) took about 60-90 seconds per fish. Photographs were taken of each tagged fish immediately following the insertion of the tag, and then the fish was placed in a recovery container with dissolved oxygen from 100 to 110 percent saturation to expedite recovery from anesthesia.

Following tagging, lamprey were held in perforated 19-L recovery containers in a tank supplied with flowing river water for a minimum of 18 hours prior to release. An acoustic receiver was deployed in the tank to monitor and confirm transmitter function. For transport to release sites, containers were transferred to an insulated tote in the bed of a truck and supplied with oxygen through a diffuser to maintain dissolved oxygen saturation between 90 and 110 percent. Water temperature in the transport tote was maintained within $2{ }^{\circ} \mathrm{C}$ of the recovery tank and river temperature at the release site.

Tagged lamprey were released at two locations. The upper release site was at the State Route 24 bridge, about 4.5 mi upstream of Wapato Dam. The lower release site was about $1.7 \mathrm{mi}$ upstream of the Yakima River mouth. We decided to release tagged lamprey at both sites to manage the risk that the macrophthalmia released at the upper site might not reach the river mouth within the 30 days of transmitter life available. The upper release site allowed fish to be monitored within the Yakima River, and the lower release site was intended to increase the likelihood that some tagged fish would be detected at the monitoring sites at McNary Dam or 
further downriver. We completed releases during daylight conditions at the lower release site and included both a daytime and a nighttime release for the upper release site to facilitate comparisons of lamprey movement behavior. Release time was recorded for each group, and lamprey within a group were released within 1 minute of other lamprey in that same group.

To evaluate potential tagging effect, we did a controlled laboratory assessment using nonfunctional ("dummy") transmitters. The dummy tags were the same dimensions as the tags for the field evaluation, and all aspects of fish collection, holding, and tagging up to the time of release matched the field study procedures. When field study fish were loaded for transport to the release sites, dummy-tagged fish were moved to the Yakima Nation Prosser Hatchery (adjacent to the Chandler facility) and transferred to glass aquaria. Tagged and untagged lamprey were held for about 30 days to evaluate tagging or handling effects. As has been reported by other researchers (Mueller and others, 2006; Mesa and others, 2012), some held lamprey developed fungal infections. To better understand potential options for controlling fungal outbreaks, we tested anti-fungal treatments on both tagged and untagged lamprey. The methods and results of the laboratory evaluation are described in Beals and Lampman (2019).

\section{Monitoring of Tagged Lamprey}

Tagged juvenile lamprey were monitored as they moved through the Yakima and Columbia Rivers by a series of acoustic receivers deployed at selected monitoring sites. All monitoring sites were selected, installed, and maintained by our study partners for their own research objectives prior to the start of our pilot study. Our study used these existing sites to monitor tagged lamprey. The juvenile salmon study (USGS-Reclamation-YNF) had eight monitoring sites in the Yakima River (fig. 1) and two sites at bridges in the Columbia River in the Tri-Cities, Washington (table 1). Monitoring sites at McNary Dam, Crow Butte, Bonneville Dam, and Camas, Washington (table 1), were installed and maintained by PNNL. The monitoring site on the Columbia River at the mouth of the Klickitat River was maintained by USGS. Multiple acoustic receivers typically were deployed to monitor a site-for example, eight receivers at Wanawish Dam and two receivers at the Yakima River mouth. We were able to share acoustic receiver detections across a series of studies because all the study partners used the JSATS, which is required to detect the prototype lamprey transmitters. All detections of tagged lamprey were gathered, and we compiled a dataset that was reviewed and proofed for analyses.

\section{Analyses}

We calculated travel time, travel rate, and residence time at and between several detection sites throughout the study area. Travel time was calculated as the difference between the last detection at one site, or the time of release, and the first detection at another site. Travel rate was expressed as miles per day and was calculated by dividing the distance between sites by the travel time for an individual fish between those sites. Residence time was the time between the first and last detection of a lamprey at a given detection site. We present travel metrics at selected detection sites - five sites for the upper site releases and four sites for the lower site releases. These sites were selected based on the number of fish detected at that site (minimum of about 20 individuals) and their spatial separation (minimum of about $2 \mathrm{mi}$ ). 
To evaluate lamprey movements relative to light and dark periods, we characterized the light condition at the time lamprey arrived at a series of detection sites. We defined four categories for light condition at time of arrival: (1) "light" began 30 minutes prior to sunrise, (2) "dark" began 30 minutes after sunset, (3) "a.m. low light" began 1 hour prior to the start of light, and (4) "p.m. low light" began 1 hour prior to the start of darkness. Using these categories, the dark condition excludes any transitional light periods.

\section{Lamprey Compared to Passive Particle Travel Metrics}

Passive particle travel times and rates were calculated from McNary to Bonneville Dams using data from the USACE (Douglas Baus, U.S. Army Corps of Engineers, written commun., December 2018). The USACE calculator required a flow input and generated a travel time and rate for a given reach. The mean daily discharge was determined for the dates on which lamprey were first and last detected at McNary and Bonneville Dams (May 10-26, 2018) and was used as the flow input to calculate passive particle travel times and rates. Particle travel times and rates were compared to lamprey travel times and rates, both as release groups and overall for all lamprey combined. The release groups moved through the McNary-to-Bonneville reach at different times within the period from May 10 to 26, but the flow conditions they experienced were similar. We compared the mean flow for each of the four release groups using the dates each group moved through the McNary-to-Bonneville reach. The means for the four groups had a maximum difference of $12,000 \mathrm{ft}^{3} / \mathrm{s}$, or 2.5 percent. The mean daily discharge for all lamprey release groups combined was used for the particle travel time and rate calculations. The distance between the dams, used to calculate travel rates for both the particles and lamprey, was 145.3 river miles.

Lamprey travel times between McNary and Bonneville Dams were compared to the predicted passive particle travel times. At these large Columbia River dams, acoustic receivers were deployed in the forebay and tailraces to improve detection capability. Ideally, lamprey travel time would be calculated as the difference between the last time a fish was detected in the McNary Dam tailrace and the first time it was detected in the Bonneville Dam forebay. This approach is ideal because it eliminates any time incurred during dam passage. We detected 26 lamprey moving between these dams that could be compared with particle travel times. At Bonneville Dam, all 26 fish were detected in the dam forebay. At McNary Dam, however, only six fish were detected in the tailrace. Using the ideal approach, the limited detections at the McNary Dam tailrace would have allowed only six fish to be used for the comparison. To estimate the potential influence of using detections in the McNary Dam forebay, we calculated the passage time at the dam as the difference between the last detection in the forebay and the first detection in the tailrace. The maximum passage time was 2.8 hours for a group of 25 lamprey that had matching detections for which the calculation could be made. Over the course of the multi-day travel time between the dams, we considered the influence of passage time to be nominal, so we accepted McNary Dam forebay detections as valid for calculation of travel time from McNary to Bonneville Dams. In cases where both a forebay and a tailrace detection were available for an individual, the tailrace detection was used for the calculation to minimize the potential bias of passage time. 


\section{Night-Only Travel Scenario}

To better understand diel lamprey movements, especially as they relate to the comparison with passive particle movement metrics, we calculated travel rates under an artificial scenario where we assumed that lamprey only traveled at night (hereinafter, "night-only travel scenario"). The night-only travel scenario assumed that lamprey only traveled during darkness, with a constant rate of travel, and stopped downstream movement during daylight periods. Our question for this scenario was how travel rates measured for the tagged lamprey in our study compared to the theoretical scenario. For this comparison, we used 26 lamprey that moved between McNary and Bonneville Dams - the same data used for the comparison with passive particle travel times and rates. We reviewed the time of last detection at McNary Dam and the time of first detection at Bonneville Dam and calculated, for each individual, the total hours of darkness and light available within this window. We defined dark to include both crepuscular periods, beginning 30 minutes prior to sunset and continuing until 30 minutes after sunrise. We used the length of the reach (145.3 river miles) and the total hours of darkness available for an individual to calculate a travel rate for the night-only travel scenario.

\section{Results and Discussion}

We completed four releases of tagged lamprey from May 9 to 15, 2018 (table 2). Two groups were released at the upper site and two groups were released at the lower site. The May 9 release at the upper release site was done at night to allow some comparison of fish behavior with the May 15 release at the upper site, which occurred during light conditions (table 2). Both releases at the lower site were done during light conditions.

\section{River Environment}

Environmental conditions in the Yakima River during our study generally were similar to the conditions during the 10-year period from 2008 to 2017. Overall, discharge during 2018 was typical of previous years, but our study activities in May occurred during the highest flows of the year (fig. 2). The May 9 and 10 releases occurred as flows were decreasing, between a peak flow on May 9 and a low flow on May 13 (fig. 3). Lamprey were released at 2130 hours on May 9, so their exposure to flow conditions began primarily on May 10. The May 15 releases were on an ascending limb of the hydrograph, with the peak flow for 2018 occurring on May 17 at 11,642 $\mathrm{ft}^{3} / \mathrm{s}$ (fig. 3). Water temperatures in 2018 were about average relative to the previous 10 years (fig. 2). In May 2018, the mean Yakima River discharge was $8,053 \mathrm{ft}^{3} / \mathrm{s}$ (standard deviation $\left.[\mathrm{SD}], 2,914 \mathrm{ft}^{3} / \mathrm{s}\right)$, and the mean water temperature was $14.6{ }^{\circ} \mathrm{C}\left(\mathrm{SD}, 1.4^{\circ} \mathrm{C}\right)$. 
Table 2. Summary of acoustically tagged juvenile lamprey released at two sites on the Yakima River, Washington, May 2018.

[Upper site was at the State Route 24 bridge, about 4.5 miles upstream of Wapato Dam. Lower site was about 1.7 miles upstream of the Yakima River mouth]

\begin{tabular}{cllcc}
\hline Site & Date & $\begin{array}{c}\text { Time } \\
\text { (hours) }\end{array}$ & $\begin{array}{c}\text { Number } \\
\text { released }\end{array}$ & $\begin{array}{c}\text { Number of } \\
\text { active tags }\end{array}$ \\
\hline Upper & May 9 & 2130 & 19 & 18 \\
Lower & May 10 & 1326 & 24 & 19 \\
Upper & May 15 & 1017 & 29 & 29 \\
Lower & May 15 & 1328 & 25 & 25 \\
\hline
\end{tabular}
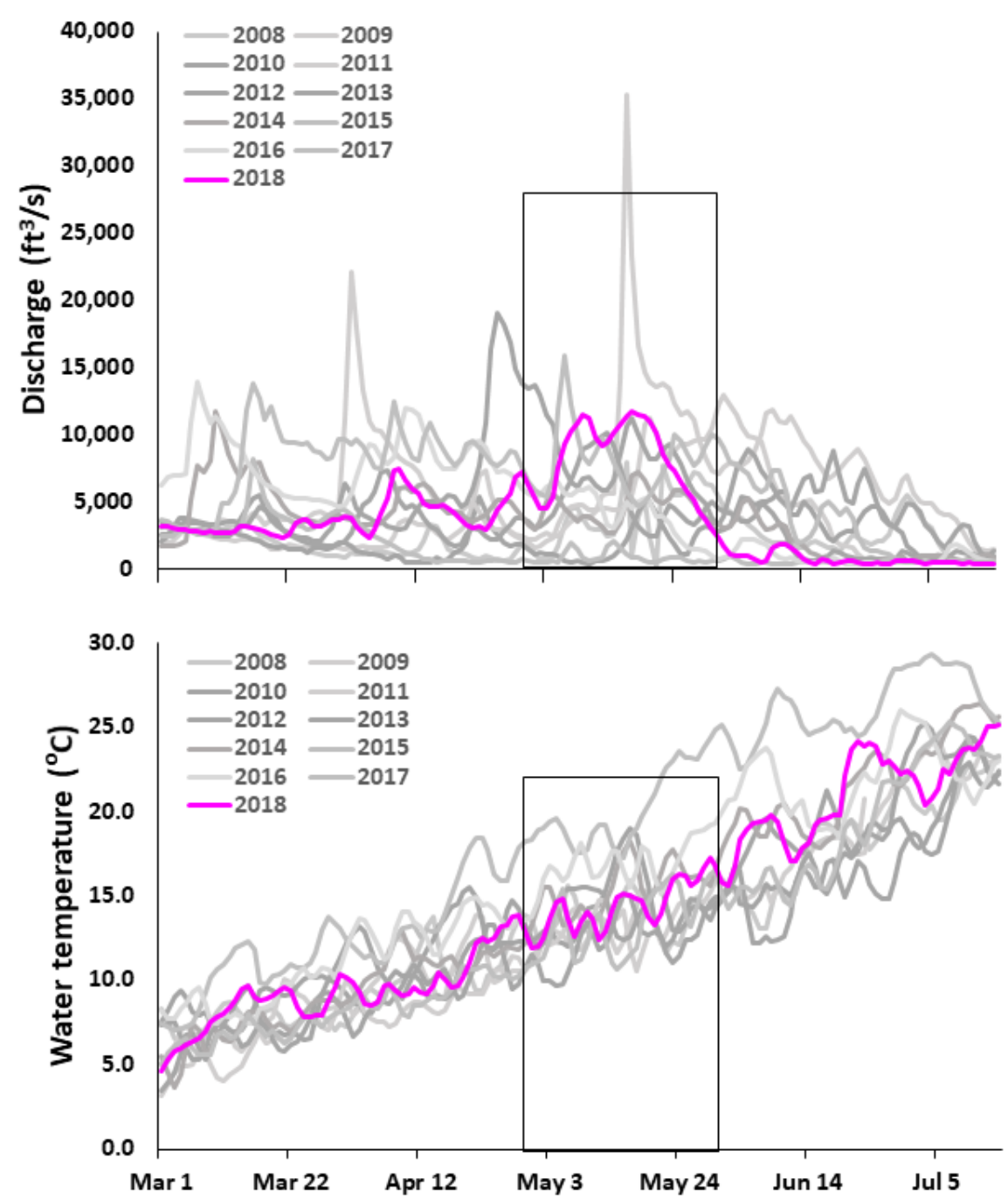

Figure 2. Graph showing discharge and water temperature in Yakima River, Washington, March-July 2018. Study period is shown in the boxed areas. $\mathrm{ft}^{3} / \mathrm{s}$, cubic foot per second; ${ }^{\circ} \mathrm{C}$, degrees Celsius. Data from https://www.usbr.gov/pn/hydromet/. 


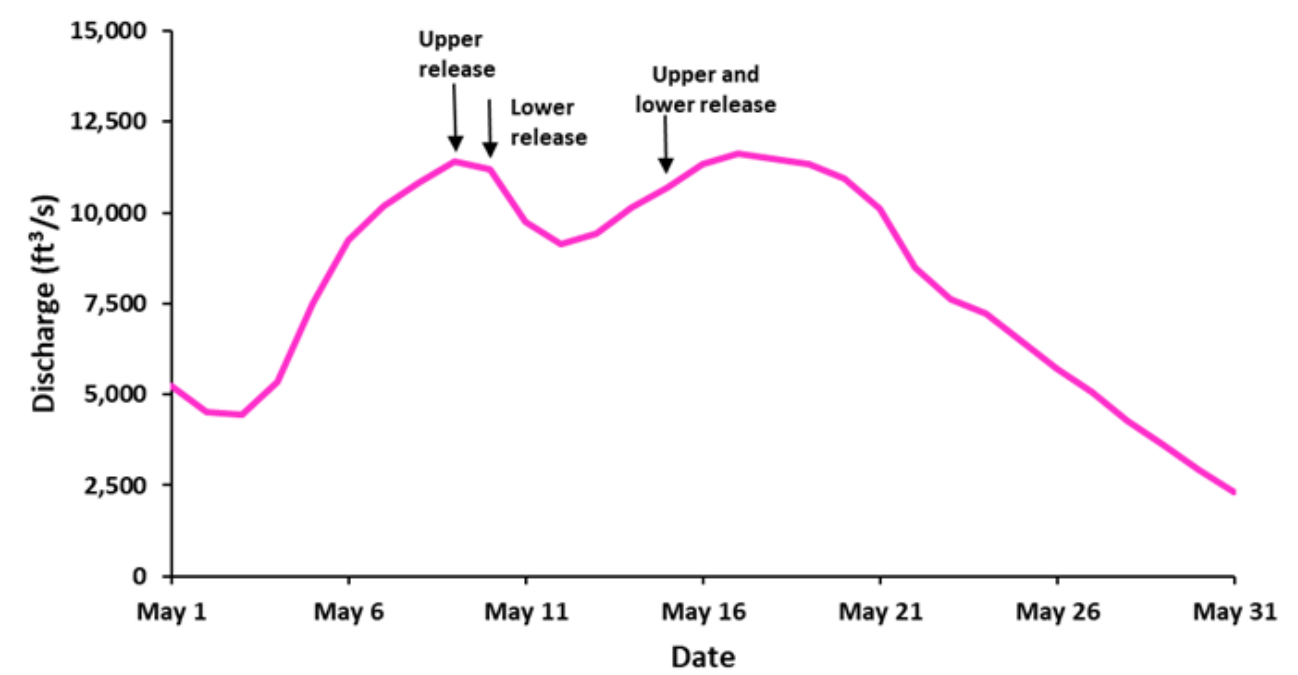

Figure 3. Graph showing releases of acoustically tagged juvenile lamprey (indicated with arrows) and discharge in Yakima River, Washington, May 2018. ft3/s, cubic foot per second. Data from https://www.usbr.gov/pn/hydromet/.

In the Columbia River, we compared discharge and water temperature during May 2018 to the 10-year average for the reach between McNary and Bonneville Dams. The 2018 discharge in this reach was higher than the 10-year average on all dates in May (fig. 4), with an overall mean for May of 436,000 $\mathrm{ft}^{3} / \mathrm{s}$. Water temperatures in this reach were similar to the 10 -year average and increased from McNary to Bonneville Dams (table 3). 


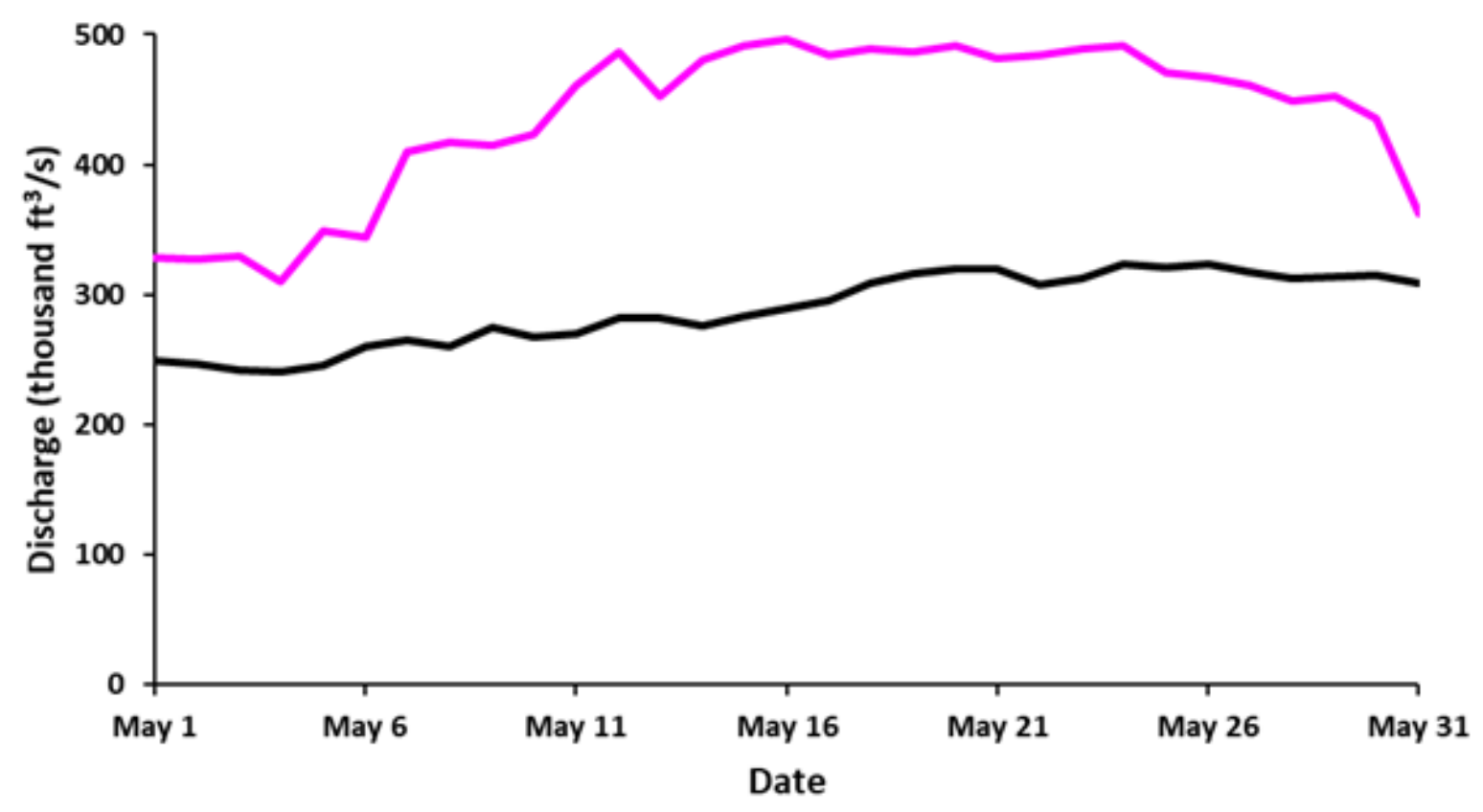

Figure 4. Graph showing mean daily discharge between McNary Dam tailrace and Bonneville Dam forebay, on the Columbia River, Washington, May 2018 (pink top line) compared to the 10-year (2008-17) mean for May (black bottom line). thousand $\mathrm{ft}^{3} / \mathrm{s}$, thousand cubic foot per second. Data from http://www.cbr.washington.edu/dart.

Table 3. Mean daily water temperatures for the Columbia River between McNary Dam and Bonneville Dams, on the Columbia River, for May 2018, and for May during the 10-year period, 2008-17.

[Data from http://www.cbr.washington.edu/dart. \pm , plus or minus standard deviation]

\begin{tabular}{lcc}
\hline \multicolumn{1}{c}{ Site } & May 2018 & May 2008-17 \\
\hline McNary Dam forebay & $12.7 \pm 1.1$ & $12.3 \pm 1.0$ \\
McNary Dam tailrace & $12.7 \pm 1.2$ & $12.4 \pm 1.0$ \\
John Day Dam forebay & $12.7 \pm 1.1$ & $12.3 \pm 1.0$ \\
John Day Dam tailrace & $13.2 \pm 1.1$ & $12.8 \pm 1.1$ \\
The Dalles Dam forebay & $13.4 \pm 1.0$ & $13.0 \pm 1.0$ \\
The Dalles Dam tailrace & $13.4 \pm 1.1$ & $13.0 \pm 1.0$ \\
Bonneville Dam forebay & $13.5 \pm 1.1$ & $13.0 \pm 1.1$ \\
\hline
\end{tabular}




\section{Lamprey Collection, Tagging, and Release}

We tagged and released 97 juvenile lamprey from May 9 to 15, 2018 (table 2). One juvenile Western River Lamprey (Lampetra ayresii), collected at the Chandler facility, was included with the May 15 release at the upper release site and all other study fish were Pacific Lamprey. One lamprey tagged on May 9 died prior to release but no other mortalities were observed. The overall mean total length for tagged lamprey was $150.0 \mathrm{~mm}$ and ranged from 138 to $176 \mathrm{~mm}$ (table 4). The overall mean weight for tagged lamprey was $4.6 \mathrm{~g}$ and ranged from 3.2 to $7.4 \mathrm{~g}$ (table 4). The mean transmitter burden (transmitter weight relative to body weight) was 1.7 percent and ranged from 1.1 to 2.5 percent. The Western River Lamprey was $154 \mathrm{~mm}$ long and weighed $3.5 \mathrm{~g}$. The sizes of lamprey for each release group were similar (table 4).

Table 4. Juvenile lamprey total length and mass for groups of acoustically tagged fish released at two sites on the Yakima River, Washington, May 2018.

[Upper site was at the State Route 24 bridge, about 4.5 miles upstream of Wapato Dam. Lower site was about 1.7 miles upstream of the Yakima River mouth]

\begin{tabular}{|c|c|c|c|c|c|}
\hline \multirow[t]{2}{*}{ Site } & \multirow[t]{2}{*}{ Date } & \multicolumn{2}{|c|}{$\begin{array}{c}\text { Length } \\
\text { (millimeter) }\end{array}$} & \multicolumn{2}{|c|}{$\begin{array}{c}\text { Mass } \\
\text { (gram) }\end{array}$} \\
\hline & & Mean & Range & Mean & Range \\
\hline Upper & May 9 & 147.4 & $138-173$ & 4.3 & $3.2-6.4$ \\
\hline Lower & May 10 & 149.3 & 139-164 & 4.7 & $3.6-6.5$ \\
\hline Upper & May 15 & 150.6 & $140-176$ & 4.6 & $3.5-7.4$ \\
\hline Lower & May 15 & 150.6 & 139-164 & 4.7 & $3.7-6.5$ \\
\hline
\end{tabular}

Lamprey were collected for tagging from 3-4 sites for each tagging date (table 5). The amount of time collected fish were held prior to tagging was variable to allow small groups of fish, collected across several days, to be combined in a single tagging-release group. For the first release group, juvenile lamprey were collected from four sites and the mean holding time was 3.1 days. Two lamprey were held for 10 days, which was the maximum holding time for the group (table 5). When lamprey from this group were examined and handled for tagging, we noted that some fish showed evidence of an early fungal infection. Previous studies have reported that fungus commonly is an issue for juvenile lamprey (Mueller and others, 2006; Mesa and others, 2012). Of the 20 fish tagged, 9 (45 percent) showed some indication of fungus, ranging from a small area of fungus near the first dorsal fin to small white or clear dots on their body. The mean holding time for fish that had fungus was 5.9 days (maximum of 10 days), and the mean holding time for fish that showed no signs of fungus was 0.9 days (maximum of 4 days). We reviewed the detection records and travel metrics for the nine fish with fungus; noted few differences compared to the remainder of the release group; and, therefore, now present pooled (fungus and non-fungus) summaries for this release group. To limit the risk of fungal infections, future tagging sessions limited the pre-tag holding time to 4 days (table 5). None of the lamprey released on May 10 or 15 had signs of fungus. Overall, 49.4 percent of the study fish came from McNary Dam, 25.7 percent came from the Chandler facility, 14.4 percent came from John Day Dam, and about 5 percent each came from Ahtanum and Toppenish Creeks.

Six tagged fish were removed from the dataset because their tags were not detected in the recovery tank prior to release or at any monitoring station downstream. All analyses were done with the 91 tags that were confirmed to be functioning (table 2). 
Table 5. Release sites and dates, collection sites and dates, and number of days fish were held prior to tagging for groups of acoustically tagged lamprey released at two sites on the Yakima River, Washington, May 2018.

[Upper site was at the State Route 24 bridge, about 4.5 miles upstream of Wapato Dam. Lower site was about 1.7 miles upstream of the Yakima River mouth]

\begin{tabular}{llllclc}
\hline \multirow{2}{*}{ Site } & $\begin{array}{c}\text { Release } \\
\text { date }\end{array}$ & $\begin{array}{c}\text { Tag } \\
\text { date }\end{array}$ & Collection site & $\begin{array}{c}\text { Number of } \\
\text { fish }\end{array}$ & $\begin{array}{c}\text { Collection } \\
\text { date }\end{array}$ & $\begin{array}{c}\text { Number of } \\
\text { days held }\end{array}$ \\
\hline Upper & May 9 & May 8 & Ahtanum Creek & 4 & May 8 & 0 \\
& May 9 & May 8 & Chandler facility & 1 & April 29 & 9 \\
& May 9 & May 8 & Chandler facility & 5 & May 7 & 1 \\
& May 9 & May 8 & John Day Dam & 1 & April 28 & 10 \\
& May 9 & May 8 & John Day Dam & 3 & May 4 & 4 \\
& May 9 & May 8 & McNary Dam & 1 & April 28 & 10 \\
& May 9 & May 8 & McNary Dam & 1 & May 1 & 7 \\
& May 9 & May 8 & McNary Dam & 2 & May 5 & 3 \\
& May 9 & May 8 & McNary Dam & 1 & May 7 & 1 \\
\hline Lower & May 10 & May 9 & Ahtanum Creek & 1 & May 9 & 0 \\
& May 10 & May 9 & Chandler facility & 10 & May 9 & 0 \\
& May 10 & May 9 & Toppenish Creek & 5 & May 9 & 0 \\
& May 10 & May 9 & McNary Dam & 8 & May 9 & 0 \\
\hline Upper & May 15 & May 14 & Chandler facility & 1 & May 10 & 4 \\
& May 15 & May 14 & Chandler facility & 1 & May 11 & 3 \\
& May 15 & May 14 & Chandler facility & 4 & May 12 & 2 \\
& May 15 & May 14 & John Day Dam & 4 & May 14 & 0 \\
& May 15 & May 14 & McNary Dam & 9 & May 11 & 3 \\
& May 15 & May 14 & McNary Dam & 10 & May 13 & 1 \\
\hline Lower & May 15 & May 14 & Chandler facility & 2 & May 10 & 4 \\
& May 15 & May 14 & Chandler facility & 1 & May 12 & 2 \\
& May 15 & May 14 & John Day Dam & 6 & May 14 & 0 \\
& May 15 & May 14 & McNary Dam & 16 & May 13 & 1 \\
\hline
\end{tabular}




\section{Detection Summary}

Overall, we detected a high proportion of tagged lamprey, with more individuals detected in the Columbia River than in the Yakima River (fig. 5). Of the 91 lamprey with confirmed functioning tags, we detected 87 (95.6 percent) on at least one acoustic telemetry receiver within our study area (table 6). Detections in the Yakima River were low overall, with most detections occurring at two locations. In the Columbia River, lamprey were detected at each of the nine monitoring sites, with the number of fish detections generally decreasing as lamprey moved downstream.

In the Yakima River, lamprey most commonly were detected in the Wanawish Dam forebay and at the river mouth. We released 47 lamprey at the upper site, and these fish potentially could have been detected on any of the monitoring sites in the Yakima River. Only 10 of these sites detected lamprey, most of them with low numbers of individuals (table 6). The site that detected the most lamprey was the Wanawish Dam forebay (38 lamprey, 80.9 percent). More than one-half (27 lamprey, 57.4 percent) of the fish from the upper release site were detected at the Yakima River mouth (table 6, fig. 5). The remaining sites in the Yakima River detected lamprey in low numbers, ranging from 1 to 12 individuals per site (table 6). Lamprey were not detected at 16 monitoring sites in the Yakima River (table 7). No lamprey were detected at monitoring sites downstream of irrigation canal fish diversion screens, including Wapato canal, Sunnyside canal, Prosser canal, and Wanawish West canal (table 7).

In the Columbia River, lamprey were detected most commonly at McNary Dam, Crow Butte, the Yakima River mouth, and Blue Bridge (table 6, fig. 5). These sites detected between 84.6 percent (McNary Dam) and 61.5 percent (Yakima River mouth and Blue Bridge) of the study fish. Small numbers of lamprey were detected at the Klickitat River mouth (five individuals), Bonneville Dam tailrace (1 individual), and Camas (2 individuals).

Lamprey released at the lower site were detected in higher proportions than lamprey released at the upper site. At all monitoring sites downstream of the lower release site, more individuals from the lower site were detected than from the upper site (fig. 5). The only exception was in the tailrace of Bonneville Dam, where only one lamprey was detected (table 6). All lamprey released at the lower site and 91.5 percent of all lamprey released at the upper site were detected somewhere in the study area (table 6). For fish released at the upper site, 100 percent of the May 9 release was detected, and 86.2 percent of the May 15 release was detected (table 6).

The Western River Lamprey released as part of our study was only detected in the forebay of Wapato Dam. It was released at the upper site on May 15 and was first detected in the dam forebay on June 3,19.5 days after it was released. The last time we detected this lamprey was on June 5, 1.3 days after it had first been detected in the forebay. There were no other detections of this fish in our study area. 

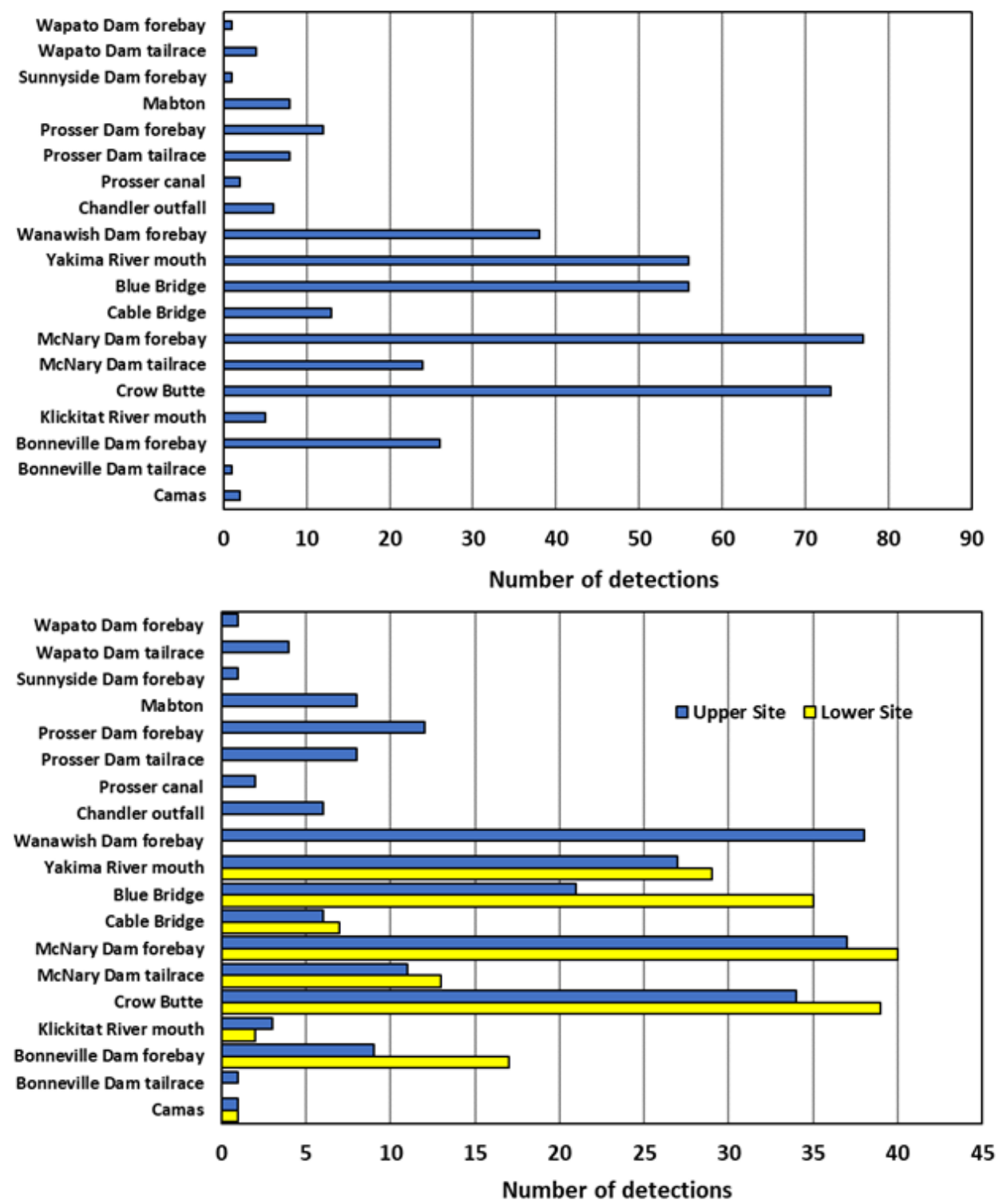

Figure 5. Graphs showing number of detections and sites where acoustically tagged juvenile lamprey were detected following release, Yakima and Columbia Rivers, Washington. Upper graph shows all releases combined and lower graph shows upper and lower sites separately. Bars represent number of individuals detected at each detection site. 
Table 6. Monitoring sites where lamprey were detected in the Yakima and Columbia Rivers, by release site and date in 2018, for groups of acoustically tagged lamprey released at two sites on the Yakima River, May 2018.

[Upper site was at the State Route 24 bridge, about 4.5 miles upstream of Wapato Dam. Lower site was about 1.7 miles upstream of the Yakima River mouth. Total fish available for detection is the sum of lamprey released upstream of the monitoring site. Total number of individual lamprey detected and percentage of total available for detection (in parentheses) are presented for each release site and date, and overall. -, not applicable]

\begin{tabular}{|c|c|c|c|c|c|c|}
\hline Monitoring site & $\begin{array}{l}\text { Upper site } \\
\text { May } 9\end{array}$ & $\begin{array}{c}\text { Lower site } \\
\text { May } 10\end{array}$ & $\begin{array}{l}\text { Upper site } \\
\text { May } 15\end{array}$ & $\begin{array}{l}\text { Lower site } \\
\text { May } 15\end{array}$ & $\begin{array}{c}\text { Total } \\
\text { detected }\end{array}$ & $\begin{array}{c}\text { Total } \\
\text { available for } \\
\text { detection }\end{array}$ \\
\hline \multicolumn{7}{|c|}{ Yakima River } \\
\hline Wapato Dam forebay & 0 & - & 1 & - & 1 & 47 \\
\hline Wapato Dam tailrace & 3 & - & 1 & - & 4 & 47 \\
\hline Sunnyside Dam forebay & 1 & - & 0 & - & 1 & 47 \\
\hline Mabton & 3 & - & 5 & - & 8 & 47 \\
\hline Prosser Dam forebay & 8 & - & 4 & - & 12 & 47 \\
\hline Prosser Dam tailrace & 4 & - & 4 & - & 8 & 47 \\
\hline Prosser canal & 1 & - & 1 & - & 2 & 47 \\
\hline Chandler outfall & 3 & - & 3 & - & 6 & 47 \\
\hline Wanawish Dam forebay & 16 & - & 22 & - & 38 & 47 \\
\hline Yakima River mouth & 4 & 13 & 23 & 16 & 56 & 91 \\
\hline \multicolumn{7}{|c|}{ Columbia River } \\
\hline Blue Bridge & 12 & 18 & 9 & 17 & 56 & 91 \\
\hline Cable Bridge & 3 & 5 & 3 & 2 & 13 & 91 \\
\hline McNary Dam forebay & 16 & 16 & 21 & 24 & 77 & 91 \\
\hline McNary Dam tailrace & 7 & 6 & 4 & 7 & 24 & 91 \\
\hline Crow Butte & 13 & 15 & 21 & 24 & 73 & 91 \\
\hline Klickitat River mouth & 1 & 0 & 2 & 2 & 5 & 91 \\
\hline Bonneville Dam forebay & 2 & 6 & 7 & 11 & 26 & 91 \\
\hline Bonneville Dam tailrace & 1 & 0 & 0 & 0 & 1 & 91 \\
\hline Camas & 0 & 1 & 1 & 0 & 2 & 91 \\
\hline \multicolumn{7}{|c|}{ All sites combined (percentages in parentheses) } \\
\hline All sites combined & $\begin{array}{l}18 \\
(100)\end{array}$ & $\begin{array}{c}19 \\
(100)\end{array}$ & $\begin{array}{c}25 \\
(86.2)\end{array}$ & $\begin{array}{l}25 \\
(100)\end{array}$ & $\begin{array}{c}87 \\
(95.6)\end{array}$ & - \\
\hline
\end{tabular}


Table 7. Monitoring sites where no acoustically tagged lamprey were detected in the Yakima River, Washington.

\begin{tabular}{l}
\hline \multicolumn{1}{c}{ Monitoring site } \\
\hline Wapato canal \\
Wapato canal downstream of screens \\
Wapato bypass outlet \\
Wapato tailrace \\
Sunnyside tailrace \\
Sunnyside bypass outlet \\
Sunnyside canal \\
Sunnyside canal downstream of screens \\
Granger \\
Prosser bypass outlet \\
Prosser canal downstream of screens \\
Wanawish West canal \\
Wanawish West canal downstream of screens \\
Wanawish East canal \\
Wanawish tailrace \\
Wanawish bypass outlet
\end{tabular}

\section{Travel Times, Travel Rates, and Residence Times}

Travel times increased with increasing distance from the release sites, as expected, and some groups had large ranges, even with relatively large numbers of fish (table 8). For example, 29 individuals released at the lower site were detected at the Yakima River mouth with a mean travel time of 1.0 day. The range of travel times for these 29 fish was from 0.02 to 16.5 days, although the distance between sites was only $1.7 \mathrm{mi}$ (table 8 ). Each release group generally had similar travel times to a detection site and the variability was due to a single fish or a few fish that moved much more quickly or slowly than the remainder of the group. For example, for the lower release site group detected at the Yakima River mouth, if the fish with the 16.5-day travel time is removed, the mean travel time for the group is 95.0 minutes instead of 1.0 day.

Lamprey arrived at Bonneville Dam in an average of 8.0-9.6 days from the upper site (about 300 river miles) and in an average of 6.4 days from the lower site (about 193 river miles). All lamprey detected at Bonneville Dam arrived within about 10-11 days (table 8). The shortest travel time to Bonneville Dam was 4.0 days for a lamprey released at the lower site (table 8).

Mean travel rates for groups of lamprey ranged from 23.7 to $38.8 \mathrm{mi} / \mathrm{d}$ (table 8 ). Individual lamprey traveled as slowly as $0.1 \mathrm{mi} / \mathrm{d}$ and as quickly as $72.5 \mathrm{mi} / \mathrm{d}$. Like the travel times on which they were based, travel rates for a given group most commonly were very similar, with a few outliers. Considering the range of distances and flow conditions the different groups were exposed to, travel rates were consistently near $30 \mathrm{mi} / \mathrm{d}$ (table 8 ). The overall mean travel rate, pooled for all release groups and detection sites, was $31.4 \mathrm{mi} / \mathrm{d}$. 
Table 8. Travel time, travel rate, and residence time for groups of acoustically tagged lamprey released under dark (shaded rows) and light (unshaded rows) conditions from two release sites on the Yakima River, Washington, May 2018.

\begin{tabular}{|c|c|c|c|c|c|c|c|c|c|}
\hline \multirow{2}{*}{$\begin{array}{l}\text { Release } \\
\text { condition }\end{array}$} & \multirow{2}{*}{ Detection site } & \multirow{2}{*}{$\begin{array}{l}\text { Distance } \\
\text { from release } \\
\text { site (miles) }\end{array}$} & \multirow{2}{*}{$\begin{array}{c}\text { Number } \\
\text { of fish }\end{array}$} & \multicolumn{2}{|c|}{$\begin{array}{l}\text { Travel time } \\
\text { (days) }\end{array}$} & \multicolumn{2}{|c|}{$\begin{array}{c}\text { Travel rate } \\
\text { (miles per day) }\end{array}$} & \multicolumn{2}{|c|}{$\begin{array}{l}\text { Residence time } \\
\text { minutes) }\end{array}$} \\
\hline & & & & Mean & Range & Mean & Range & Mean & Range \\
\hline \multicolumn{10}{|c|}{ Upper release site } \\
\hline Dark & Wanawish Dam forebay & 92.8 & 16 & 3.3 & $2.2-5.2$ & 29.4 & $17.8-42.2$ & 3.1 & $1.4-5.2$ \\
\hline Light & Wanawish Dam forebay & 92.8 & 22 & 3.0 & $1.5-4.5$ & 32.7 & $20.5-61.1$ & 2.2 & $0.3-3.3$ \\
\hline Dark & Yakima River mouth & 108.9 & 4 & 2.9 & $2.5-3.1$ & 37.6 & $35.0-44.5$ & 1.1 & $0.4-2.6$ \\
\hline Light & Yakima River mouth & 108.9 & 23 & 3.5 & & 33.0 & $20.0-64.6$ & 2.6 & $1.0-6.5$ \\
\hline Dark & McNary Dam forebay & 153.5 & 16 & 5.2 & $3.5-7.0$ & 30.8 & $22.1-43.4$ & 33.0 & $5.0-268.0$ \\
\hline Light & McNary Dam forebay & 153.5 & 21 & 4.6 & $2.7-6.8$ & 34.4 & $22.5-56.1$ & 11.0 & $5.0-32.0$ \\
\hline Dark & Crow Butte & 184.0 & 13 & 5.9 & $4.6-7.4$ & 31.9 & $24.7-39.9$ & 5.6 & $4.0-10.0$ \\
\hline Light & Crow Butte & 184.0 & 21 & 5.4 & $3.3-7.5$ & 35.7 & $24.4-56.3$ & 5.7 & $3.0-10.0$ \\
\hline Dark & Bonneville Dam forebay & 300.2 & 2 & 9.6 & $9.1-10.0$ & 31.5 & $30.0-33.1$ & 1.0 & $0.5-1.0$ \\
\hline Light & Bonneville Dam forebay & 300.2 & 7 & 8.0 & $6.2-10.9$ & 38.8 & $27.4-48.7$ & 1.1 & $0.5-2.0$ \\
\hline \multicolumn{10}{|c|}{ Lower release site } \\
\hline Light & Yakima River mouth & 1.7 & 29 & 1.0 & $0.02-16.5$ & 23.7 & $0.1-72.5$ & 2.6 & $0.5-5.9$ \\
\hline Light & McNary Dam forebay & 46.3 & 40 & 1.7 & $0.9-5.4$ & 30.7 & $8.6-50.3$ & 13.5 & $6.0-69.0$ \\
\hline Light & Crow Butte & 76.7 & 39 & 3.5 & $1.4-26.4$ & 30.1 & $2.9-54.0$ & 28.1 & $3.0-884.0$ \\
\hline Light & Bonneville Dam forebay & 192.9 & 17 & 6.4 & $4.0-9.9$ & 31.9 & $19.4-48.1$ & 1.2 & $0.5-2.0$ \\
\hline
\end{tabular}


Residence times at detection sites were consistently low. Mean residence times for groups ranged from 1.0 to 33.0 minutes (table 8$)$. The two highest mean residence times $(33.0$ and 28.1 minutes) were both influenced by a single fish in the group with exceptionally high residence time. One lamprey was resident at McNary Dam forebay for 4.5 hours (268 minutes) and another was resident at Crow Butte for 14.7 hours (884 minutes) (table 8). The next highest residence time we measured for any site was 69.0 minutes, and there were only 11 instances (of 270 total movements) of residence times longer than 20 minutes in the dataset. The overall mean residence time, pooled for all release groups and detection sites, was 10.6 minutes.

The two upper site releases, one during the day and one at night, showed some differences in movement metrics. Overall, travel times for upper site release groups differed more than residence times. There were five detection sites at which these groups could be compared, from Wanawish Dam to Bonneville Dam (table 8). The group released during the day had slightly faster mean travel times than the group released at night at 4 of the 5 detection sites (table 8). The magnitude of the difference was 0.3 days at Wanawish Dam and 1.6 days at Bonneville Dam, with the other detection sites falling between these extremes at 0.5-0.6 days (table 8). Residence times were short, and similar at 4 of the 5 detection sites (table 8). The highest residence times for both groups occurred at McNary Dam, where the night release group had a mean of 33.0 minutes and the day group had a mean of 11.0 minutes. The night release group had one fish with an extended residence time of 268 minutes. When that fish was excluded, the adjusted mean residence time for the night release group was 17.6 minutes, and the difference between the groups was 6.6 minutes. The group released at night, overall, had slower travel times at most detection sites and a slightly longer residence time at one site, compared to the group released during the day.

\section{Light Condition at Time of Arrival at Detection Sites}

Most lamprey arrived at detection sites during periods of darkness. Across all release groups and detection sites, 63.0 percent of lamprey arrivals occurred during darkness (table 9). The remainder of arrivals were 28.5 percent light, 3.3 percent a.m. low light, and 5.2 percent p.m. low light (table 9). Only 8.5 percent of lamprey arrivals occurred during the two transitional light conditions combined. The combination of release site and detection site resulted in 14 groups that were used to summarize light condition at time of arrival. Of these 14 groups, 11 groups arrived predominantly in the dark, and 3 groups arrived predominantly in the light (table 9). The detection sites where groups arrived predominantly in the light were the low reaches in our study area, at Crow Butte and Bonneville Dam. One group detected at Bonneville Dam was released at the lower site during the day and had predominantly night arrival for the Yakima River mouth, McNary Dam, and Crow Butte before arriving at Bonneville Dam primarily under light conditions (table 9). Both upper site release groups (one day and one night release) arrived predominantly under dark conditions at the Wanawish Dam forebay, 93 mi downstream of the release location (table 9). As lamprey moved downstream, both groups continued to arrive predominantly under dark conditions at the Yakima River mouth and at McNary Dam, although the numbers of individuals arriving under light and transitional light categories increased (table 9). At Crow Butte and Bonneville Dam the day release arrived predominantly under light conditions, and the night release arrived predominantly in the dark. 
Table 9. Light condition at time of arrival for groups of acoustically tagged juvenile lamprey released under dark (shaded rows) and light (unshaded rows) conditions at two sites on the Yakima River, Washington, May 2018.

$[-$, not applicable $]$

\begin{tabular}{|c|c|c|c|c|c|c|c|c|}
\hline \multirow[b]{2}{*}{$\begin{array}{l}\text { Release } \\
\text { condition }\end{array}$} & \multirow[b]{2}{*}{ Detection site } & \multirow[b]{2}{*}{$\begin{array}{l}\text { Number } \\
\text { of fish }\end{array}$} & \multicolumn{5}{|c|}{ Light condition at time of arrival } & \multirow[b]{2}{*}{$\begin{array}{c}\text { Change of } \\
\text { light } \\
\text { condition }\end{array}$} \\
\hline & & & Dark & $\begin{array}{l}\text { Low light } \\
\text { (a.m.) }\end{array}$ & Light & $\begin{array}{l}\text { Low } \\
\text { light } \\
\text { (p.m.) }\end{array}$ & $\begin{array}{c}\text { Summary } \\
\text { (percentage) }\end{array}$ & \\
\hline \multicolumn{9}{|c|}{ Upper release site } \\
\hline Dark & Wanawish Dam forebay & 16 & 13 & 0 & 1 & 2 & 81.3 Dark & 0 \\
\hline Light & Wanawish Dam forebay & 22 & 20 & 0 & 0 & 2 & 90.9 Dark & 0 \\
\hline Dark & Yakima River mouth & 4 & 3 & 0 & 1 & 0 & 75.0 Dark & 0 \\
\hline Light & Yakima River mouth & 23 & 19 & 0 & 1 & 3 & 82.6 Dark & 0 \\
\hline Dark & McNary Dam forebay & 16 & 8 & 0 & 6 & 2 & 50.0 Dark & 1 \\
\hline Light & McNary Dam forebay & 21 & 15 & 1 & 5 & 0 & 71.4 Dark & 1 \\
\hline Dark & Crow Butte & 13 & 8 & 0 & 4 & 1 & 61.5 Dark & 0 \\
\hline Light & Crow Butte & 21 & 6 & 0 & 15 & 0 & 71.4 Light & 0 \\
\hline Dark & Bonneville Dam forebay & 2 & 2 & 0 & 0 & 0 & 100.0 Dark & 0 \\
\hline Light & Bonneville Dam forebay & 7 & 1 & 0 & 5 & 1 & 71.4 Light & 0 \\
\hline \multicolumn{9}{|c|}{ Lower release site } \\
\hline Light & Yakima River mouth & 29 & 17 & 0 & 11 & 1 & 58.6 Dark & 0 \\
\hline Light & McNary Dam forebay & 40 & 28 & 2 & 10 & 0 & 70.0 Dark & 0 \\
\hline Light & Crow Butte & 39 & 26 & 5 & 7 & 1 & 66.7 Dark & 4 \\
\hline Light & Bonneville Dam forebay & 17 & 4 & 1 & 11 & 1 & 64.7 Light & 0 \\
\hline \multicolumn{9}{|c|}{ Both release sites (percentages in parentheses) } \\
\hline $\begin{array}{l}\text { Light and } \\
\text { dark }\end{array}$ & All sites combined & 270 & $\begin{array}{l}170 \\
(63.0)\end{array}$ & $\begin{array}{c}9 \\
(3.3)\end{array}$ & $\begin{array}{c}77 \\
(28.5)\end{array}$ & $\begin{array}{l}14 \\
(5.2)\end{array}$ & - & $\begin{array}{c}6 \\
(2.2)\end{array}$ \\
\hline
\end{tabular}


Lamprey released on two dates at the lower site had different light conditions on arrival at the Yakima River mouth, $1.7 \mathrm{mi}$ downstream of the release site. The two releases occurred on May 10 and 15 at about 1330 hours (table 2). For the May 10 release, 13 lamprey were detected at the Yakima River mouth (table 6), and 10 of these fish (76.9 percent) arrived in less than 1 hour, under light conditions. The first lamprey to arrive was detected 33.2 minutes after release. Three lamprey had longer travel times; two were detected from 4 to 8.5 hours after release and one did not arrive for 16.5 days (table 8). For this group, most lamprey moved quickly downstream following release and arrived at the river mouth during daylight. For the second release, on May 15, 16 lamprey were detected at the Yakima River mouth (table 6), and the first fish to arrive had a travel time of 7 hours and arrived under p.m. low-light conditions. A total of 13 lamprey had travel times from 7 to 8.6 hours, with 12 of these lamprey arriving after dark (75 percent). Three lamprey had longer travel times, ranging from 2.3 to 2.4 days, all arriving after dark. For this group, most lamprey delayed downstream movement or moved more slowly, arriving at the river mouth about 6 hours later than the first release group, and in the dark. When the groups were pooled, the dominant light condition on arrival was dark (table 9), but the behavior of the fish seemed to be different between these releases. We have no evidence that the groups had different handling, tagging, or transport experiences. The May 15 release had lower flow conditions and warmer water temperature than the May 10 release, but the differences were nominal. Mean discharge was $11,176 \mathrm{ft}^{3} / \mathrm{s}$ on May 10 and 10,698 $\mathrm{ft}^{3} / \mathrm{s}$ on May 15, a difference of $478 \mathrm{ft}^{3} / \mathrm{s}$, or 4.4 percent. Water temperature was $13.7^{\circ} \mathrm{C}$ on May 10 and $15.1^{\circ} \mathrm{C}$ on May 15 , a difference of $1.4^{\circ} \mathrm{C}$.

Few lamprey experienced a change in light condition while they were resident at a detection site; that is, they moved into a detection area (first detection time) and out of the same detection area (last detection time) under the same light condition. Overall, across all release groups and detection sites, 2.2 percent of these movements (6 of 270) occurred across a change of light condition (table 9). The low incidence of these events likely was due to the consistently low residence times at detection sites. Short residence times, however, did not preclude a change of light, as 4 of the 6 events that had a change of light condition had residence times less than 18 minutes. These four fish arrived at Crow Butte (table 9) during a transitional light condition and were last detected at the light or dark condition that immediately followed. The remaining two events were in the McNary Dam forebay and had more extended residence times. One lamprey released at the upper site at night arrived at McNary Dam under p.m. low-light conditions, about 1 hour prior to full darkness, was resident for 4.5 hours, and was last detected under dark conditions. The final fish to experience a change of light condition was released at the upper site during the day, arrived at McNary Dam under a.m. low-light conditions, was resident for 32 minutes, and was last detected under full daylight.

We detected one lamprey that remained at a detection site through the full daylight period, apparently only moving downstream when it became dark. This lamprey was released on May 10 at the lower site and was detected at Crow Butte on May 13. It arrived early in the morning, about 30 minutes after daylight, remained resident at the site for 14.7 hours, and departed under p.m. low-light conditions, about 40 minutes prior to darkness. This extended residence time was the highest we recorded (table 8) and was fully within light or transitional light periods. This lamprey arrived at Crow Butte as the light was increasing and remained there until the light was decreasing. No other fish in the study had a similar profile. 


\section{Lamprey Compared to Passive Particle Travel Metrics}

Overall, lamprey moved more slowly than passive particles in the reach between McNary and Bonneville Dams, but some individuals and one group exceeded particle travel rates. All four release groups experienced similar Columbia River flow conditions as they traveled between McNary and Bonneville dams (fig. 6). The difference in mean flow between the groups was a maximum of $12,000 \mathrm{ft}^{3} / \mathrm{s}$, or 2.5 percent. The two releasees on May 15 had the highest mean flows and the May 10 release had the lowest mean flow (fig. 6). The predicted particle travel rate was $43.6 \mathrm{mi} / \mathrm{d}$, which was faster than 3 of the 4 lamprey release groups as well as the overall lamprey travel rate for all groups combined (fig. 6). The May 15 upper site release group had a mean travel rate of $48.7 \mathrm{mi} / \mathrm{d}$, which exceeded the particle travel rate. Overall, seven individual lamprey (27.0 percent) met or exceeded the particle travel rate, with travel rates ranging from 47.9 to $70.3 \mathrm{mi} / \mathrm{d}$ (fig. 6). However, the sample size for the overall group was 26 fish, and individual release groups had sample sizes ranging from 2 to 11 lamprey. Comparisons of individual release groups with particle travel rates should be interpreted cautiously.

The estimated particle travel time from McNary to Bonneville Dams was 3.3 days, and the mean travel time for the combined lamprey release groups was 4.4 days (fig. 6). The lamprey were, on average, 1.1 days slower in this reach than passive particles. The fastest lamprey group, from the upper release site on May 15, arrived at Bonneville Dam in a mean of 3.2 days. The seven lamprey that did not exceed particle travel time arrived between 7 and 30 minutes faster than the particles. The group with the longest travel time was the May 10 release, and it arrived with a mean of 4.9 days, lagging behind the particle time by 1.6 days. 

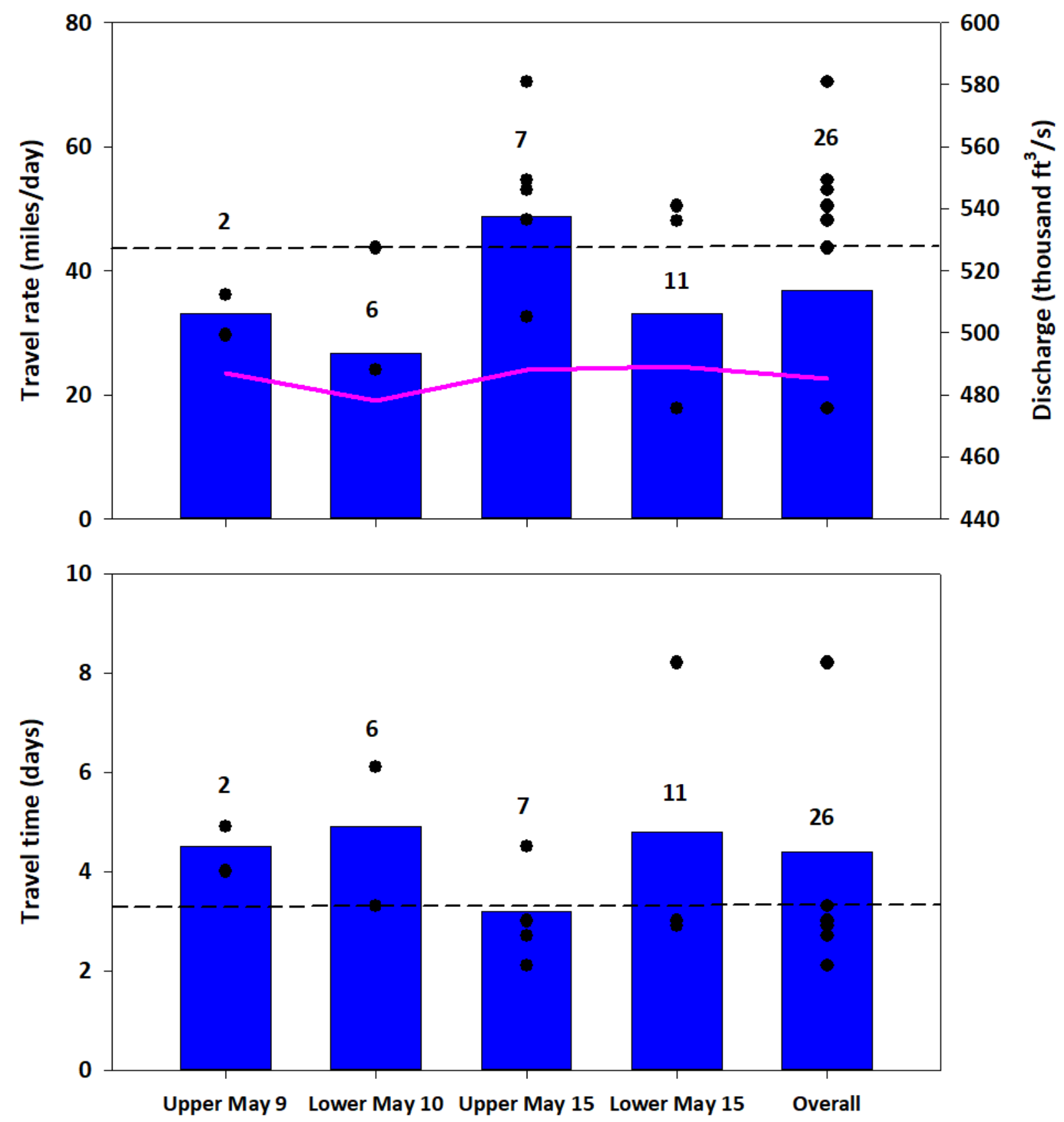

Figure 6. Graphs showing mean juvenile lamprey travel rates (in miles per day [miles/day]; upper graph) and travel times (in days; lower graph) between McNary and Bonneville Dams for four groups of fish released at two locations in the Yakima River, Washington, May 2018. Mean flow for each group and for overall (all groups pooled) is shown on the secondary axis (pink curved line). Passive particle travel rate and travel time are shown with a dashed line in each graph. Samples sizes for each bar are presented over the bar. Circles represent the minimum and maximum for each group and outliers. thousand $\mathrm{ft}^{3} / \mathrm{s}$, thousand cubic foot per second. 


\section{Night-Only Travel Scenario}

\section{Scenario Rationale and Approach}

The findings from the comparison of lamprey travel times and rates with those of passive particles led to questions about lamprey movement strategies. Although studies of juvenile lamprey movements have been limited, it is assumed that lamprey prefer to travel at night and may have limited or no movements during daylight periods. Our summary of light condition at time of arrival at detection sites provides some support for this assumption as lamprey arrived predominantly under dark conditions. The detection data, however, provide snapshots of movement timing, with limited residence time spent near detection sites. A true picture of a travel pattern cannot be visualized with the detection data alone. For example, the detection data consist of the date and time that a lamprey arrived at and departed from McNary Dam, and the date and time that the same lamprey arrived at Bonneville Dam. Although we can calculate the travel time and rate and describe the light conditions at both detection sites while the lamprey was present, we lack any information about movements within the reach between the dams or whether the travel rate was steady or variable over time. The comparison of mean lamprey travel times with particle travel times showed that lamprey arrived at Bonneville Dam 1.1 days after passive particles would have arrived. This result could be explained by at least two potential movement scenarios: (1) lamprey moving nonstop through the reach, at an average rate less than the passive particle rate; or (2) lamprey moving at the particle rate or faster, but for a period less than the total travel time (that is, there are some periods of non-movement). Considering the assumption that lamprey tend to move only at night, and our finding that lamprey arrived at detection sites predominantly in the dark, we were interested in investigating the second scenario, where the non-movement periods occurred during daylight hours. To evaluate the night-only travel scenario, we used the 26 lamprey that moved between McNary and Bonneville Dams and divided their total travel time into periods of darkness and light. We divided the distance between the dams ( 145.3 river miles) by the total hours of darkness available to an individual fish to get the theoretical rate for the night-only travel scenario. This theoretical travel rate is assumed to be constant over the hours of darkness.

\section{Scenario Summary}

The theoretical travel rate generated under the night-only travel scenario was more than double the mean travel rate we measured for lamprey that moved between McNary and Bonneville Dams. The theoretical mean travel rate under the night-only travel scenario was 89.2 $\mathrm{mi} / \mathrm{d}$ (range, $42.2-165.3 \mathrm{mi} / \mathrm{d}$ ). The mean lamprey travel rate through the McNary-to-Bonneville reach, as measured during this study, was $36.7 \mathrm{mi} / \mathrm{d}$ (range, $17.7-70.3 \mathrm{mi} / \mathrm{d}$ ). The highest travel rate we observed in this reach was $70.3 \mathrm{mi} / \mathrm{d}$, and the highest rate we measured anywhere in our study area was $72.5 \mathrm{mi} / \mathrm{d}$ (table 8 ), both of which are 16-19 mi/d less than the mean rate for the scenario.

The mismatch between the theoretical travel rates and the observed travel rates has several possible explanations. One explanation is that lamprey traveled at least partially during daylight periods. There is some evidence for this based on the time of arrival at detection sites. Another explanation is an elevated nighttime travel rate, exceeding the observed overall travel rate. Our dataset cannot evaluate this potential explanation as our detection sites were widely separated and lamprey moved through several day-night cycles as they transited between the dams. This comparison ideally would be made in a study reach that lamprey could transit in a 
short period (less than about 8 hours) so that daytime- or nighttime-specific travel rates could be estimated. Our 2018 pilot study was limited in this regard, but we expect that the 2019 evaluation will provide additional opportunities to describe juvenile lamprey migration behavior.

Lamprey movements likely are a combination of the two potential explanations. They likely travel at least somewhat during daylight (perhaps at a reduced rate or with periods of rest) and travel at higher rates at night.

\section{Additional Discussion}

This 2018 pilot acoustic telemetry study, done in a collaborative setting, provided valuable insights into the movements of juvenile Pacific Lamprey. We detected a high proportion of our study fish (95.6 percent), and three of the four release groups had 100 percent detection. Detections of lamprey in the Yakima River were limited at most sites, but larger groups of fish $(15+)$ were detected at two sites, and these became the primary sites used for our summary and comparisons between groups. The detection arrays in the Yakima River were not designed to provide detailed passage route information for lamprey, but it was difficult to describe even broad patterns of routing such as potential entrainment into irrigation diversions owing to the limited detections at many sites. Large groups of lamprey were detected at several sites in the Columbia River, allowing us to define a series of reaches over which we could summarize lamprey travel behavior. Without the collaborative approach that allowed access to detection data from the arrays in the Columbia River, much less would have been learned. The combination of the detection sites in both the Yakima and the Columbia Rivers allowed us to more fully describe lamprey movements over a series of reaches and a wide range of distances. We estimate that our detections, especially in the Yakima River, could have been improved using a transmitter with a 3 -second pulse rate interval, rather than the 5-second-interval transmitter that we used. We anticipate that a transmitter using a 3 -second pulse rate interval will have a battery life of about 18 days. Nothing was known about the travel rate of juvenile lamprey to guide a decision on a pulse rate interval that might maximize detections and because we wanted to maximize transmitter life, we selected the 5-second pulse rate interval for the pilot study. Transmitter testing and development have advanced, and we now know that lamprey are capable of high movement rates, at least under the study conditions present in 2018, so future studies may benefit from a transmitter with a modified pulse rate interval.

Lamprey moved through our study area at an average rate of 30-35 mi/d and generally remained at each detection site for less than about 20 minutes. Groups of lamprey showed variability, but the common trend was for most fish in a group to have very similar travel rates or residence times, and 1-2 fish in the group to have very different movement patterns with much longer or shorter rates or times. For our dataset, river conditions (flow and water temperature) do not seem a likely driver of this difference in behavior because all lamprey in a group typically moved through our study reaches within a day or so of the rest of the group and river conditions were relatively stable over that interval. Perhaps the differences we observed are similar to the findings of Deng and others (2018) that small numbers of their study fish did not seem to be disposed to move downstream following release. With few studies of juvenile lamprey movements, little was known about their travel rates. Deng and others (2018) used the same transmitter in a field test in the Columbia River and reported median travel rates from 43.2 to $69.6 \mathrm{mi} / \mathrm{d}$ over a $7-\mathrm{km}$ study area. Our study groups traveled from 2 to 300 river miles (3.3$482.8 \mathrm{~km}$ ) and had mean travel rates from about 30 to $39 \mathrm{mi} / \mathrm{d}$. The maximum travel rates we observed ranged from about 40 to about $73 \mathrm{mi} / \mathrm{d}$, and compare well with Deng and others (2018). 
The residence times at our detection sites were consistently low (most commonly 1-3 minutes), suggesting that lamprey moved directly past these sites without delay. Residence times may have been influenced by the limited detection range for this tag, estimated at 80-140 $\mathrm{m}$ (Deng and others, 2018) if the lamprey was near the detection site, but out of detection range.

Passive particle travel rates exceeded lamprey travel rates for most groups that traveled between McNary and Bonneville Dams. The mean travel rate for all the release groups combined was about $7 \mathrm{mi} / \mathrm{d}$ slower than the particle travel rate, but one of the release groups exceeded the particle rate by about $5 \mathrm{mi} / \mathrm{d}$. Expressed as travel time, particles made the trip in 3.3 days, and the pooled lamprey groups took 4.4 days. The fastest lamprey group arrived in 3.2 days, just slightly faster than the particle travel time. We made this comparison because the lamprey travel rates we observed were high, and lamprey are not strong swimmers (Moursund and others, 2000; Moser and others, 2015), so our hypothesis was that they might be traveling with the bulk flow, either by choice or because it was so powerful that they could not resist. The results suggest that lamprey are not moving passively with the bulk flow through the entire reach. They may match or exceed particle travel rates at times and then have periods of non-travel, or they may be traveling at reduced rates throughout the reach. The passive particle travel rates were generated using data from the USACE that were developed to help manage the hydropower system. Although the particle travel rate information was useful and interesting, it may not accurately predict the flow conditions experienced by juvenile lamprey. We are likely to learn a lot more in the coming years about the depth profiles of migrating juvenile lamprey now that we can monitor their movements with telemetry, but from what is currently known, lamprey seem to be deeper in the water column than juvenile salmonids. Without an air bladder, juvenile lamprey tend to sink unless they are actively swimming. Additionally, they show a strong affinity to be attached to substrate during daylight hours (Moursund and others, 2000). Mesa and others (2015) summarized juvenile lamprey migration and passage findings in the Columbia and Snake Rivers and reported that very few juvenile lamprey would be routed into juvenile bypass systems and were much more likely to be entrained into turbines because they approached the dams deeper than juvenile salmon. Deng and others (2018) did field testing with the lamprey-eel transmitter and reported a median depth of $8.5 \mathrm{~m}$ for juvenile lamprey. The particle travel rates are based primarily on surface water, and since lamprey tend to be deeper in the water column and are likely to be spending time attached to hard substrates on the bottom of the river, lamprey likely experience different flow conditions.

Lamprey arrived at detection sites predominantly during the dark, but we also found evidence that some travel occurred during daylight and transitional light periods. Our detection sites were widely separated, lamprey needed 1 day or more to transit between them (several daynight cycles), and they did not remain near our sites for more than about 20 minutes. Our detection records, therefore, give us a simplified view of lamprey movements between detection sites. If lamprey had extended residence times at our sites, we could compare the fraction of the resident time that was light and dark to learn when movements were initiated and terminated. Lacking extended residence times, we summarized the light condition at the time lamprey were first detected at our sites to learn more about their diel movements. Overall, about 63 percent of lamprey arrival times at detection sites were in the dark, about 29 percent were during daylight, and about 9 percent were during transitional light periods. Considering that in May, each 24-hour period is composed of 60-65 percent light (based on the light categories we defined), the high proportion of night arrivals for juvenile lamprey supports the premise that they tend to travel after dark. Goodman and others (2015) also reported that most macrophthalmia moved at night 
and in the early morning hours, especially associated with high-flow events. These authors suggest that turbidity associated with high-flow events effectively extends the low-light conditions lamprey prefer for movement (Goodman and others, 2015). We looked at lamprey movement rates under the night-only travel scenario. The scenario showed that lamprey would have required travel rates faster than any travel rate we measured during our study. Based on the difference between theoretical and observed travel rates, we concluded that the night-only travel scenario was not a good fit to our data, and that lamprey likely completed some travel during daylight hours or moved at higher rates than the observed rate during darkness. Lamprey are primarily nocturnal, and Moursund and others (2000) estimated that more than 90 percent of juvenile lamprey activity occurred during dark periods. These authors also noted that during laboratory studies, juvenile lamprey had a strong affinity for the substrate or the bottom of the tank during daylight hours (Moursund and others, 2000). Although they show a preference for activity at night, juvenile lamprey do not swim continuously throughout dark periods but stop intermittently and attach to substrates (Moser and others, 2015). In laboratory studies, about 15 percent of macrophthalmia remained attached throughout a 12-hour dark period (Moursund and others, 2000). We saw similar variability in our dataset, with a preference for movements at night, but evidence that some lamprey were actively moving during the daylight hours.

Our 2018 pilot study generated new data on juvenile lamprey travel rates and diel movement patterns in the Yakima and Columbia Rivers, and helped address critical information gaps for this life stage. The project is scheduled to do a similar field study in 2019 and 2020, continuing the partnership with the lower Yakima River juvenile salmon study. One of the goals of our pilot study was to improve our understanding of how to best conduct a telemetry study of juvenile lamprey to guide future field efforts. We plan to use a transmitter with a shorter (3second) pulse rate interval in 2019 to improve our ability to detect lamprey at sites in the Yakima River. Additional detections will help us to describe routes that lamprey use to move around or through dams, irrigation diversions, or barriers. We hope that additional detections will also allow more detailed descriptions of daytime- and nighttime-specific travel rates. For the pilot study, we explored the option to collect fish from various sources and hold them until there were enough fish for a rigorous release group. We found some fish with fungus, likely attributable to extended holding. For 2019, we plan to limit pre-tag holding to a maximum of 4 days, at which we did not observe negative effects in 2018. Ideally, if enough fish are available, we would tag fish the day they were collected to control the risk of fungal infections. Only the upper release site will be used in 2019 so that all study fish will have the potential to be detected at the monitoring arrays in the Yakima River. We expect that 2019 will have different environmental conditions and, therefore, will be a useful addition to the 2018 pilot study. 


\section{Acknowledgments}

We thank Scott Evans and Maggie Cornett (U.S. Geological Survey), and Pacific Northwest National Laboratory staff for the installation and maintenance of the acoustic monitoring receivers. Maggie Cornett also assisted with tagging. We thank Mark Johnston (Yakama Nation Fisheries) and his staff at the Chandler fish facility for collecting juvenile lamprey for tagging. Yakama Nation Fisheries staff with the Lamprey Project collected juvenile lamprey from a range of locations to provide fish for tagging. Bob Rose (Yakama Nation) assisted with the effort to coordinate and fund this research.

\section{References Cited}

Beals, T., and Lampman, R., 2019, Survival assessment of juvenile Pacific Lamprey implanted with a dummy acoustic tag for a Yakima Basin acoustic telemetry study, Appendixes 3.3 and H1 of Yakama Nation Pacific Lamprey project 2018 annual progress report: Joint report prepared for the Bureau of Reclamation (Cooperative Agreement No. R15AC00044), Boise, Idaho, and U.S. Department of Energy, Bonneville Power Administration (Project No. 2008470-00), Portland, Oregon, 21 p.

Clemens, B.J., Wyss, L., McCoun, R., Courter, I., Schwabe, L., Peery, C., Schreck, C.B., Spice, E.K., and Docker, M.F., 2017, Temporal genetic population structure and interannual variation in migration behavior of Pacific Lamprey Entosphenus tridentatus: Hydrobiologia, v. 794, no. 1, p. 223-240. [Also available at https://doi.org/10.1007/s10750-017-3096-4.]

Deng, Z.D., Carlson, T.J., Li, H., Xiao, J., Myjak, M.J., Lu, J., Martinez, J.J., Woodley, C.M., Weiland, M.A., and Eppard, M.B., 2015, An injectable acoustic transmitter for juvenile salmon: Scientific Reports, v. 5, article number 8111, https://doi.org/10.1038/srep08111.

Deng, Z.D., Titzler, P.S., Mueller, R.P., Lu, J., Martinez, J.J., Fu, T., Li, H., Cable, J.S., Deters, K.A., Hubbard, J.M., and Colotelo, A.H., 2018, Pilot field trial of the juvenile lamprey/eel tag and RME plan to guide future juvenile pacific lamprey acoustic telemetry studies: Prepared by Pacific Northwest National Laboratory Richland, Washington, for the U.S. Department of Energy under Contract DE-ACO\%-76RL01830.

Goodman, D.H., Reid, S. B., Som, N.A., and Poytress, W.R., 2015, The punctuated seaward migration of Pacific Lamprey (Entosphenus tridentatus) -Environmental cues and implications for streamflow management: Canadian Journal of Fisheries and Aquatic Sciences, v. 72, no. 12, p. 1817-1828. [Also available at https://doi.org/10.1139/cjfas-2015-0063.]

Johnson, E.L., Caudill, C.C., Keefer, M.L., Clabough, T.S., Peery, C.A., Jepson M.A., and Moser, M.L., 2012, Movement of radio-tagged adult Pacific Lampreys during a large-scale fishway velocity experiment: Transactions of the American Fisheries Society, v.141, no. 3, p. 571-579. [Also available at https://doi.org/10.1080/00028487.2012.683468.]

Keefer, M.L., Caudill, C.C., Clabough, T.S., Jepson, M.A., Johnson, E.L., Peery, C.A., Higgs, M.D., and Moser, M.L., 2013, Fishway passage bottleneck identification and prioritization-A case study of Pacific Lamprey at Bonneville dam: Canadian Journal of Fisheries and Aquatic Sciences, v. 70, no. 10, p. 1551-1565. [Also available at https://doi.org/10.1139/cjfas-20130164.]

Liedtke, T.L., Beeman, J.W., and Gee, L.P., 2012, A standard operating procedure for the surgical implantation of transmitters in juvenile salmonids: U.S. Geological Survey Open-File Report 2012-1267, 50 p., https://doi.org/10.3133/ofr20121267. 
Liedtke, T. L., and Wargo-Rub, M.A., 2012, Techniques for telemetry transmitter attachment and evaluation of transmitter effects on fish performance, in Adams, N.A., Beeman J.W., and Eiler, J.H. eds., Telemetry techniques - User guide for fisheries research: Bethesda Maryland, American Fisheries Society, p. 45-87.

McIlraith, B.J., Caudill, C.C., Kennedy, B.P., Peery, C.A., and Keefer, M.L, 2015, Seasonal migration behaviors and distribution of adult Pacific Lampreys in unimpounded reaches of the Snake River Basin: North American Journal of Fisheries Management, v. 35, no. 1, p. 123134. [Also available at https://doi.org/10.1080/02755947.2014.986344.]

Mesa, M.G., Copeland, E.S., Christiansen, H.E., Gregg, J.L., Roon, S.R., and Hershberger, P.K. 2012, Survival and growth of juvenile Pacific Lampreys tagged with passive integrated transponders (PIT) in freshwater and seawater: Transactions of the American Fisheries Society, v. 141, no. 5, p. 1260-1268. [Also available at https://doi.org/10.1080/00028487.2012.686951.]

Mesa, M.G., Weiland, L.K., Christiansen, H.E., and Peery, C.A., 2015, Synthesis of juvenile lamprey migration and passage research and monitoring at Columbia and Snake River Dams: U.S. Geological Survey Report for U.S. Army Corps of Engineers, Portland, Oregon.

Moser, M.L., Jackson, A.D., Lucas, M.C., and Mueller, R.P., 2015, Behavior and potential threats to survival of migrating lamprey ammocoetes and macrophthalmia: Reviews in Fish Biology and Fisheries, v. 25, no. 1, p. 103-116. [Also available at https://doi.org/10.1007/s11160-014-9372-8.]

Moser M.L., Keefer, M.L., Pennington, H.T., Ogden, D.A., and Simonson, J.E., 2011, Development of Pacific Lamprey fishways at a hydropower dam: Fisheries Management and Ecology, v. 18, no. 3, p. 190-200. [Also available at https://doi.org/10.1111/j.13652400.2010.00773.x.]

Moser, M.L., Ocker, P.A., and Sandford, B.P., 2007, Effects of surgically implanted transmitters on anguilliform fishes - Lessons from lamprey: Journal of Fish Biology, v. 71, no. 6, p. 18471852. [Also available at https://doi.org/10.1111/j.1095-8649.2007.01628.x.]

Moser, M.L., Ocker, P.A., Stuehrenberg, L.C., and Bjornn, T.C., C.B., 2002, Passage efficiency of adult Pacific Lampreys at hydropower dams on the lower Columbia River, USA: Transactions of the American Fisheries Society, v. 131, no. 5., p. 956-965. [Also available at https://doi.org/10.1577/1548-8659(2002)131<0956:PEOAPL>2.0.CO;2.]

Moursund, R.A., Dauble, D.D., and Bleich, M.D., 2000, Effects of John Day Dam bypass screens and project operations on the behavior and survival of juvenile Pacific Lamprey (Lampetra tridentata): Pacific Northwest National Laboratory Report prepared for U.S. Army Corps of Engineers, Portland, Oregon.

Mueller, R.P, Moursund, R.A., and Bleich, M.D., 2006, Tagging juvenile Pacific Lamprey with passive integrated transponders - Methodology, short-term mortality, and influence on swimming performance: North American Journal of Fisheries Management, v. 26, no. 2, p. 361-366. [Also available at https://doi.org/10.1577/M05-017.1.]

Starcevich, S.J., Gunckel, S.L., and Jacobs, S.E., 2014, Movements, habitat use, and popular characteristics of adult Pacific Lamprey in a coastal river: Environmental Biology of Fishes v. 97, no. 8, p. 939-953. [Also available at https://doi.org/10.1007/s10641-013-0196-5.] 

Publishing support provided by the U.S. Geological Survey Science Publishing Network, Tacoma Publishing Service Center

For more information concerning the research in this report, contact the Director, Western Fisheries Research Center

U.S. Geological Survey 6505 NE 65th Street

Seattle, Washington 98115-5016

https://www.usgs.gov/centers/wfrc 


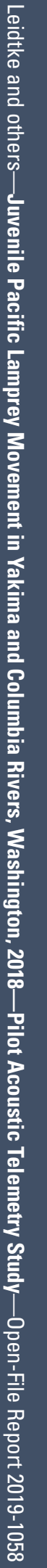

